\title{
Ultrastructural Studies of the Hyperplastic Islets of Langerhans of Spiny Mice (Acomys Cahirinus) Before and During the Development of Hyperglycemia*
}

\author{
Raymond Pictet, Lelio Orot, Alats E. Gonet, Charles Roulller and Albert E. Renold \\ Department of Histology and Embryology, and Department of Clinical Biochemistry, \\ University of Geneva, Switzerland
}

Summary. Acomys Cahirinus, the spiny mouse, is a small rodent living in the semi-desertic areas of the Eastern Mediterranean. The observation that diabetes may occur spontaneously in this species, at least under laboratory conditions, has led to its breeding at the Institut de Biochimie Clinique, where a colony has been maintained over the last 3 years. Diabetes occurs in approximately $15 \%$ of the animals reaching one year of age; some of these are obese, but not all. Diabetes occurs in the presence of, and despite a striking hyperplasia of the endocrine pancreas, which may make up as much as $15 \%$ of the total organ in adult mice. This hyperplasia is present in all animals, whether hyperglycemic or not. The islets of Langerhans of 22 spiny mice have been examined with the electron microscope and form the basis for an analysis of the different cell types observed, at different times relative to the onset of diabetes. Findings in the B cells of this species have included the generally high degree of development of the Golgi complex, the great variability of glycogen accumulation in diabetic animals, the frequent fusion of the granular sacs, and the occurrence of grossly hyper-granulated cells. - The hyperplasia of the islets of Langerhans in spiny mice is associated with a remarkable cellular polymorphism. However, the authors do not feel that this is the result of the presence in these islets of many distinct cell types. It would seem much more likely, that they represent different functional states of a small number of djstinct types of cells, among which only A, B and perhaps D cells have been securely identified. Another feature of this cellular polymorphism is the frequent presence of mixed or intermediate cells (exocrine-endocrine, or endocrino A-B), which suggests that the stimulation leading to hyperplasia of the endocrine cells in this species might result in the removal of some part of the nuclear inhibition usually associated with fully differentiated cells.

Etude ultra-structurale des îlots de Langerhans hyperplastiques de la souris a piquants (Acomys cahirinus) avant et pendant le développement d'un syndrome diabétique.

Résumé. L'Acomys Cahirinus ou souris à piquants est un rongeur vivant dans les régions semi-désertiques de l'est de la Méditerranée. La découverte d'un diabète spontané chez certains de ces animaux a fait entreprendre l'élevage d'une colonie dans laquelle ce syndrome s'est maintenu jusqu'à maintenant. Ill atteint environ 15\% des animaux, qu'ils soient obèses ou non. II apparaît sur un terrain insulaire très particulier puisque le pancréas endocrine montre une hyperplasie très importante jusqu'à constituer $15 \%$ du pancréas total. Cette hyperplasie existe chez tous les animaux, hyperglycémiques ou non. - L'étude au microscope électronique est encore trop incomplète pour une analyso corrélative détaillée entre les données métaboliques et morphologiques. Flle permet toutefois de décrire les différentes structures cellulaires de l'Acomys ainsi que leurs modifications dans les conditions pathologiques. Les changements du complexe de Golgi et des mitochondries et certains aspects plus pathologiques,comme l'accumulation de glycogène, sont

* Supported in part by grants-in-aid from the Fonds national suisse de la recherche scientifique (Grants Nr. 3618 and 4237) and from the Fondation Emil Barell pour le développement des recherches médicoscientifiques. décrits ainsi que des images plus particulières à l'Acomys, telles les confluences de vésicules et les cellules hypergra. nulées. - L'extrême hyperplasie du pancréas endocrine de la souris à piquants s'accompagne à son niveau d'un grand polymorphisme cellulaire. Les différentes cellules ainsi observées sont interprétées comme des aspects de différents moments physiologiques et non comme des types cellulaires particuliers. Ces données font conclure à la non-existence d'autres entités cellulaires que les cellules A, B et éventuellement D. Un aspect particulièrement intéressant de la souris à piquants est celui de la présence de cellules mixtes. Cette image est discutée dans le cadre très particulier du syndrome diabétique observé chez l'Acomys.

Elelktronenmikroskopische Untersuchungen der hyperplastischen Langerhans'schen Inseln der Stachelmaus (Acomys cahirinus) vor und während der Entwicklung eines diabetischen Syndroms.

Zusammenfassung. Acomys cahirinus, die Stachelmaus, ist ein kleines Nagetier, das in den an die Wüsto grenzenden Gegenden des östlichen Mittelmeerraumes lebt. Da in dieser Tierart Spontandiabetes auftritt, zumindest in Laboratoriumszucht, halten wir dieses Tier am Institut de Biochimie Clinique seit etwas mehr als drei Jahren. Diabetes mellitus tritt bei ungefähr $15 \%$ der Tiere die ein Jahr alt werden ein; einige davon sind fettsüchtig, nicht aber alle. Diabetes erscheint trotz einer sehr stark entwickelten Hyperplasie der Langerhans'schen Inseln, die bis zu $15 \%$ des erwachsenen Organs ausmachen können! Diese Hyperplasie ist bei allen Tieren zu sehen, unabhängig davon ob eine diabetische Stoffwechselstörung vorliegt oder nicht. Mit dem Elektronenmikroskop haben wir die Langerhans'schen Inseln von 22 Stachelmäusen untersucht und berichten hier über die verschiedenen beobachteten. Zelltypen, zu verschiodenen Zeitpunkten der Entwicklung der diabetischen Stoffwechselstörungen. Befunde an den B-Zellen dieser Tierart betreffen die hochgradige Entwicklung des Golgi Apparates, die große Unterschiedlichkeit und manchmal extreme Glycogen-Ablagerung in diabetischen Tieren, die häufige Verschmelzung der Membranen der Granula, und das Auftreten von ganz übermäßig hypergranulierten Zellen. - Die Hyperplasie der Langerhans'schen Inseln in Stachelmäusen geht mit einem betrachtenswerten zellulären Polymorphismus einher. Die Autoren sind jedoch nicht der Meinung, daß diese Befunde auf das Vorhandensein von vielen verschiedenen Zelltypen in diesen Inseln deutet. Es scheint ihnen viel wahrscheinlicher, daß es sich um verschiedene funktionelle Zustände einer kleinen Anzahl von Zelltypen handelt, wobei nur A, B, und vielleicht $D$ Zellen mit Sicherheit als identifiziert gelten können. Ein besonders frappanter Aspekt dieses zellulären Polymorphysmus ist die häufige Beobachtung von gernischten oder Intermediärzellen (exokrin-endokrin sowie auch endokrin A-B). Diese Beobachtung wirft die Frage auf ob die Stimulation, die zu der Hyperplasie des endokrinen Systems in dieser Tierart führt, vielleicht mit einer Verminderung der nuklearen Hemmung, die bei voll differenzierten Zellen die Regel ist, einhergehen könnte.

Key-words: Spontaneous Diabetes, Spiny mice, Acomys eahirinus, Obesity, Pancreas, Ultrastructure, Beta cells, Insulin in pancreas, Glycogen, Islets of Langerhans, Endo-exocrine cells. 
The occurence of striking congenital hyperplasia of the islets of Langerhans in spiny mice (Acomys Cahirinus) together with frequent development of obesity and/or diabetes mellitus has recently been reported. $[13,14]$. In a preliminary note, we have also reported the occurence, in this species, of intermediate cells, both endocrine and exocrine cells in the pancreatic islets of Langerhans [33]. Because of the great theoretic interest which may attach to the latter observation, a systematic study of the ultramicroscopic structure of. the islets of Langerhans has been undertaken in this species and forms the main object of this report. However, we shall first briefly summarize the present state of our knowledge concerning the occurence of diabetes and/or obesity in our colony.

After the fortuitous discovery of the syndrome in two animals which may or may not have been related to our present colony, the latter was developed from four pairs obtained from the colony of Acomys Cahirinus maintained by FLÜCKIGER [10], in Basel, Switzerland, through the branch of that colony maintained in the Department of Zoology of that University. We have been informed that all of these animals descend from a group of Acomys Cahirinus imported into Switzerland from Israel. Our experience now covers approximately 300 animals born in our colony and it should first be stated that all animals which have so far been examined at autopsy, whatever the age, have exhibited a rather extraordinary development of the islets of Langerhans, with both polynesia and macronesia, all approximately to the same degree. The hyperplasia concerned primarily the B-cells of the islets of Langerhans, an observation which is confirmed by the large amount of insulin (up to 100 units per gram wet weight) contained in the pancreas of nondiabetic individuals of this species. With the onset of diabetes, there is degranulation, then hydropic and ballooning degeneration of the islets of Langerhans, but no disappearance of the endocrine cells. Of course, we have as yet not been able to examine the pancreas of animals which had been severely diabetic for a prolonged period of time. The life expectancy of nondiabetic animals in a laboratory environment would seem to be 3 to 5 years.

Obesity is frequent in these animals, but we cannot say, at the present time, whether obesity is a genetically determined variant, or not. Whereas a bimodal distruibution of weights was suggested at first [14] it is quite clear from the data shown in Fig. 1 that this bimodality has not persisted with increasing numbers of observations. The appearance is rather that of an unusually wide range of weights for these animals, at least when raised in a laboratory environment. It is of course possible, that this wide weight range is the result of the overlapping of two separate groups, but present information does not justify such a conclusion.

Diabetes may be observed in conjunetion with obesity, but also in animals clearly in the lower weight range. The presence of diabetes was considered as established whenever there was both persistent glycosuria $(0.2 \%$ or more) and a blood glucose level exceeding $160 \mathrm{mg} / 100 \mathrm{ml}$, with random blood sampling. The distribution of blood glucose values in $\mathbf{1 4 5}$ random samplings is shown in Fig. 2. Of the first 93 animals

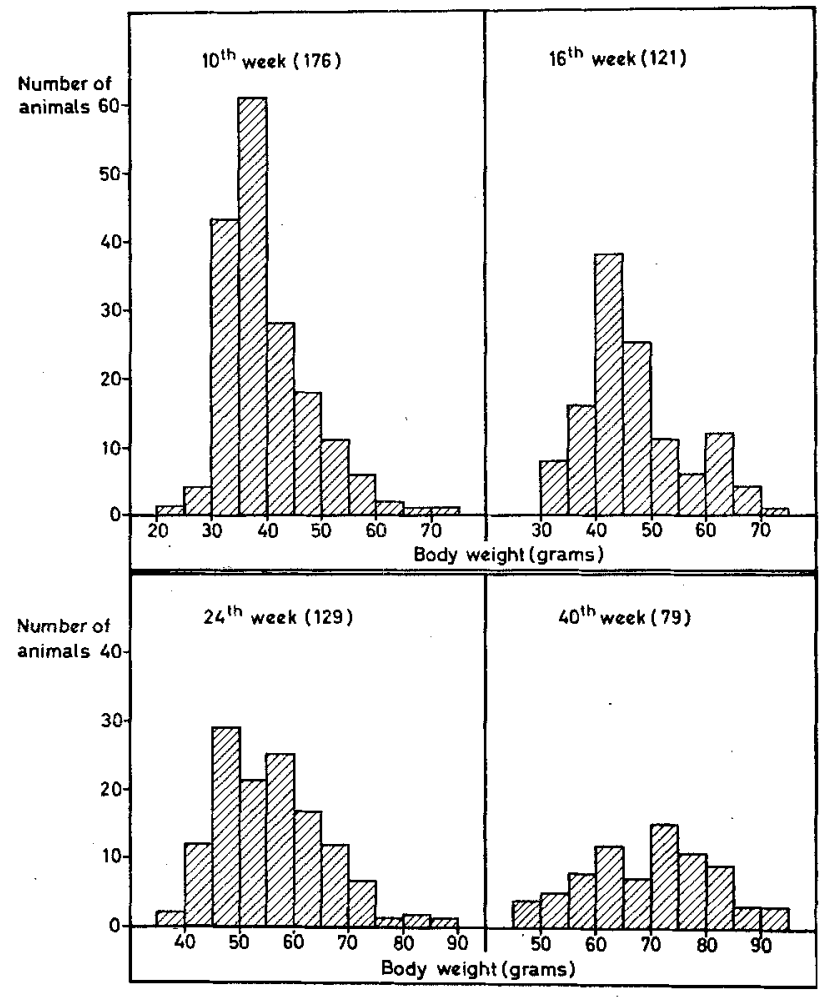

Fig. 1. Weight distribution among spiny mice at the ages of $10,16,24$ and 40 weeks respectively. The variation in numbers results from the exclusion of pregnant females

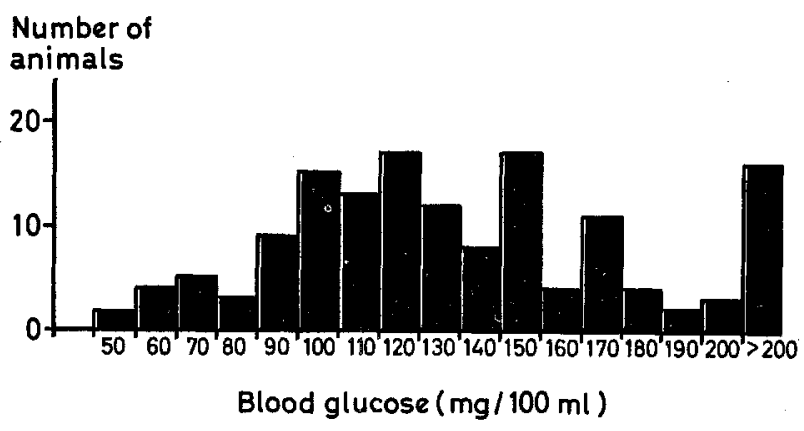

Fig. 2. Blood glueose distribution among 145 random samplings in 93 spiny mice

which have now reached a minimum age of 11 months, approximately one half have shown diabetes by this criterion. In 21 the findings were persistent, while in another 19 glycosuria was clearly of intermittent type. Thirteen of the animals having exhibited persistent glycosuria and hyperglycemia by the age of 11 months or more exhibited increasing severity of the diabetic state, with weight loss and ketosis. Thus, the overall incidence of severe diabetes in a group of 93 animals observed until at least the age of 11 months was approximately 15 percent. 
There seemed to be a tendency for diabetes to occur at two moments in life, either between the ages of 2 and 5 months, or between one and two years However, it will be necessary to observe a much larger group of animals, before this impression can be accepted as a fact. Another impression is that preliminary attempts at inbreeding are yielding families with greater than average incidence of diabetes, and also families with lesser than average incidence of diabetes. Again, a much larger number of observations is required before such an impression can be accepted. In general, diabetic males continue to be fertile, whereas diabetic females no longer contribute to enlarging the colony since fetal deaths become a serious problem.

In several of the severly diabetic animals we have observed, in addition to ketosis, the occurrence of marked, visible lipemia, severe fatty infiltration of the liver, and spontaneous coronary atheromatosis, a most unusual finding in small laboratory mammals [35].

The findings which concern the morphology of the endocrine cells of the islets of Langerhans will now be discussed in more detail.

\section{Materials and methods}

The animals, the conditions under which they were raised, and the techniques utilized for light microscopy, have been previously described [14]. All animals sacrificed in our colony undergo systematic study with the light microscope and, among these, we have selected 22, either with a normal blood sugar or at different stages of elinical evolution of diabetes, for parallel study with the electron microscope. Pancreatic fragments approximately $1 \mathrm{~mm}$ thick were fixed at $4^{\circ}$ over two hours in a $2 \%$ solution of osmium tetroxide buffered with s-collidine and also containing $0.3 \%$ $\mathrm{NaCl}, \quad 0.02 \% \quad \mathrm{MgCl}_{2}, \quad 0.02 \% \quad \mathrm{CaCl}_{2}$ and $0.017 \%$ $\mathrm{NaH}_{2} \mathrm{PO}_{4}, \mathrm{pH}$ being adjusted to 7.3. Additional fragments were prefixed in a solution of $2.5 \%$ glutaraldehyde in phosphate buffer, $\mathrm{pH} 7.45$ and osmolarity 440 mosm, and postfixed in osmium tetroxide buffered with s-collidine, osmolarity being adjusted to 320 mosm with $\mathrm{Na}_{2} \mathrm{SO}_{4}$. All the features described in this report have been seen with both fixation procedures. The fragments were dehydrated in ethanol and embedded in Epon as described by LUFT [28]. Semi-thin sections were observed in the phase contrast microscope [29] or after staining with toluidine blue. The silver-gold sections for electron microscopy were stained according to KARnovsky [18] and observed with the Zeiss EM9 and RCA EMU 2 instruments.

\section{Results}

With light microscopy, observation of the endocrine pancreas revealed 3 phases correlated with clinical evolution. In non-diabetic animals, obese or not, the striking hyperplasia and hypertrophy of the islets of Langerhans, primarily of the B-cells, was confirmed. The B-cells appeared well granulated when coloured with aldehyde-thionine [15] and Gomori's [12] aldehyde-fuchsin. In animals with mild diabetes, there was marked degranulation of the B-cells but no decrease in their number. With increasing severity of the disorder, an ever increasing number of B cells were seen to be loaded with glycogen and, in extreme cases, these glycogen-loaded cells made up a major portion of each islet. It should be stated, however, that the frequent occurence of remission in the course of the diabetes of these animals has made a strict correlation between clinical and morphological findings difficult. We do not consider it appropriate, therefore, to correlate in detail the metabolic and the morphologic observations in the animals reported here.

With the electron microscope, the different morphologic aspects of the syndrome can be appreciated in much greater detail: the $A$ cells (Fig. 4) are easily recognized by their dense granules, somewhat variable in diameter, with tightly fitting vesicular membranes. In addition, these granules are differentiated from those of $\mathrm{B}$ cells by their higher and more constant density. In the new-born, the granules are often larger (Fig. 4d) and thus are easily seen with the light microscope in fine sections (Fig. 3d). The Golgi complex is arranged in circular or spiral fashion and its vesicles present evidence of the initial stages of synthesis of the granules in the form of dots of a density quite similar to that of the granules outside of the Golgi complex (Fig. 4c and d). The mitochondria are relatively small and do not exhibit the polymorphism usually seen in B cells (Fig. $4 \mathrm{~b}$ ). The rather sparse granular endoplasmic reticulum is unremarkable.

Only rare so-called $D$ cells (Fig. 4a) have been observed and resemble those which we have seen in Swiss albino mice or in the rat. The appearance is that described in the literature [3, 31, 32].

The $B$ cells contain organelles considerably more variable in shape and structure. In the new-born of non-diabetic mothers, a small number of vesicles not containing granules were observed principally in the Golgi region (Fig. 6a). At this stage, this region is made up of a great number of small Golgi complexes, or dictyosomes, consisting of stacks of 4 or 5 saccules surrounded by vesicles. Some "coated vesicles" [2] are also seen as well as tubular structures similarly made up of double membranes to which we have given, by analogy, the name of "coated tubules" (Fig. 6a). Both these structures are seen in the $B$ cells of adult animals as well. The mitochondria do not differ from those seen in A cells. The granular reticulum is poorly developed. In adult animals, the B cells vary remarkably as to the number of granules which often have the appearance of rectangular crystals [19, 20, 27] (Fig. 16a; Fig. 18b). The density of the granules as well as the fit of the surrouding vesicles vary greatly (Figs. $6 \mathrm{~b}, 16$ and 17). The Golgi region is, in most instances, strikingly developed and gives the appearance of resulting from the fusion and hypertrophy of several Golgi complexes (Fig. 6b and c). Occasionally, it may surround the nucleus almost entirely. The mitochondria are smaller 
than in the exocrine cells and quite variable from one $B$ cell to another (Fig. 5, 7, 13). Their shape appears normal (Fig. $7 \mathrm{~b}$ ) in cells with relatively structureless cytoplasm, indicating a low degree of activity. In those cells, however, where the abundance of ribosomes and the hypertrophy of the Golgi region suggest considerable cellular activity, the mitochondria are variously and often severly deformed, frequently showing dilated cristae (Fig. 7). The granular endoplasmic reticulum may be localized to a limited area of the cell (Fig. $4 \mathrm{a}$ and 5) and, in richly granulated cells, often exhibits a dense polyribosomal population (Fig. 8). The appearance of "Nebenkern" or "fingerprints" is exceptional.

There are different morphological alterations, which may suggest diminished or absent function. The most frequent is that of glycogen storage, which is characterized by the appearance of increasing numbers of small granules in the cytoplasm, resulting first in sheetlike areas, ultimately in complete cramming of the cell (Fig. 9-12). Although we have not been able to relate the distribution of glycogen to any cytoplasmic structure (Fig. 10a), it is true that glycogen rarely accumulates to a major extent in the Golgi complex or in an area of granular endoplasmic reticulum [38, 39] (Fig. $10 \mathrm{a}$ and 12). Whatever cytoplasm persists during glycogen storage has a normal appearance (Fig. 9-12), while the nucleus is often remarkably deformed (Fig. 10b).

Another aspect of $\mathrm{B}$ cell pathology is that of vesicular confluency or vesicular fusion (Fig. 13 and 14), which may be limited to a small cytoplasmic region, or extend to an entire cell or even to a cell group. First, there is a fusion of two or three vesicles (Fig. 14a), associated with almost complete absence of insulin granules. In its most extreme form (Fig. 14b and c) the fusion process reduces the cytoplasm to thin strips, which may explain the lumpy appearance of the $B$ cells when seen under the light microscope.

A structural anomaly which may be seen at all stages of clinical progression is characterized by the presence of bodies and areas of varying sizes and made up of material with a lacquered appearance, usually surroundet by a net of concentric membranes (Fig. 15). We consider that this structure is likely to be an expression of cellular degeneration, and, in certain instances, extensive areas of this type may give the $B$ cells the appearance of pseudo-adipocytes.

At all stages of clinical evolution, including animals with normal blood glucose, grossly hyper-granulated $B$ cells may be seen (Fig. 16 and 17). These cells are crammed with a very large number of vesicles of variable size, many of them larger than in normal $B$ cells. They may contain typical B granules, some of them crystalline, or a variable amount of material of greater or lesser density. The cytoplasm between these vesicles contains many free or membrane-bound ribosomes. At the surface of these cells, granular release is frequently observed by the process of emeiocytosis
(Fig. $16 \mathrm{~b}$ and c) as described by LACY [21], and also observed in other tissues by other authors [37, 40].

Another feature of the cellular polymorphism so strikingly present in Acomys is the occurence of plurinucleated cells. Some of these are dark, stellated cells, which appear to be deformed by the lighter, neighbouring cells (Fig. 18). They do not otherwise differ from $\mathrm{B}$ cells in general and their significance will be discussed below.

The last cellular type observed in the islets of spiny mice, and perhaps the strangest, is the "mixed" or "intermediate" cell. Fig. 19 clearly illustrates the extreme interdigitation which may exist between the exocrine and the endocrine pancreas. This interpenetration is seen with both the light and the electron microscope within individual cells. These mixed or intermediate cells, which we have described previously [33], may be of several types: exocrine-endocrine $A$, exocrine-endocrine $\mathrm{B}$, exocrine-endocrine $\mathrm{A}$ and $\mathrm{B}$ (Fig. 19), and endocrine A and B. In each specific instance, the appearance of the granules of the endoplasmic reticulum, of the mitochondria, and of the Golgi region, clearly define the specific nature of the cell functions or cell types involved.

\section{Discussion}

Structural studies are single exposures of a moving field, and are thus difficult to interpret in terms of the dynamic evolution of a pathological process. Some conclusions, however, can be drawn from the comparison between such single exposures taken at different stages of the clinical evolution of the process under study, as well as from the association of different morphologic features. For example, abnormally shaped mitochondria were remarkably numerous in those cells which exhibited considerable activity, as attested by the accumulation of granules, the extent of the Golgi complex, the frequent free ribosomes, and the well-developed endoplasmic reticulum. These same deformations were not seen in either B cells poor in granules and in cytoplasmic structures, or in exocrine pancreas (Fig. 8a), A cells (Fig. 4b), or liver of the same animals, thereby excluding the possibility of an artefact. Whether the mitochondrial deformation is characteristic of $\mathrm{B}$ cell activity in general, or only of pathological $B$ cell activity, cannot be concluded from our data, although similar changes have already been described in the $B$ cells of diabetic animals $[5]$ or in different conditions of different cells $[1,25,11,26,30,34,36]$.

$A$ second index of a high degree of $B$ cell activity is overabundance of granules observed in certain instances (Fig. 16 and 17). This granular "cramming" suggests hyperactivity rather than interference with granule release because of the frequent observation, in the same cells, of structures suggestive of active emeiocytosis [21] (Fig. 16 b and c). This is in contrast to the infrequent observation of this process in other $B$ cells, probably because of the speed of the vesicular fusion with the cell membrane, with almost immediate 
solubilization of the granule in the extra-cellular space.

The existence of a second secretory process, involving intracellular solubilization of the granules has been suggested by Lazarow [23]. Confirmatory evidence of such a process in Acomys may be inferred from observations made on four siblings of a diabetic mother, two of which were examined at birth, when glycosuria was present, while the other two were observed on the next day, when glycosuria had disappeared. The almost total lack of granules in the glycosuric new-born mice, together with "empty" vesicles, suggested to us that insulin was synthetized and secreted in soluble form without the occurence of granulation, which might be an obligatory step for storage prior to secretion only when synthesis exceeds demand. The ultrastructural appearance of degranulation in B cells also suggests intracellular solubilization of insulin, since these cells are by no means empty, but often filled with typical vesicles, which appear either to be empty or to contain a material of weak electron density.

The nature and the origin of the "lacquered" material present in certain B cells (Fig. 15) is as yet unknown. However, the photographs occasionally show transitions between the granules and the lacquered areas suggesting that the granules may contribute to this type of degeneration (Fig. 15a). This suggestion is strengthened by the direct relationship which exists between the number of granules of any one cell and the extent of the lacquered area in it.

We have found it difficult to base estimates of cellular activity upon the appearance and quantity of the granular endoplasmic reticulum alone. There was no evident proportionality between the number of granules and the development of the granular endoplasmic reticulum, although a definitive statement must await a quantitative study. Similarly, the interpretation given by Volk to the "fingerprint" structures as indices of hyperactivity does not seem applicable in our findings, since we have not observed them under metabolic conditions rather similar to those described by VoLK [39].

Glycogen storage has often been observed previously in $B$ cells with the electron microscope, although perhaps never to the extent shown here (Fig. $10 \mathrm{~b}$ and $1 \mathrm{~b})$. An interesting feature is that of the absence of any morphologic expression of a reaction of the cells to the massive accumulation of glycogen, suggesting that glyeogen does not interfere with qualitative or quantitative function of whatever cytoplasm is preserved. It would seem that glycogen gradually fills areas of hyaloplasm without interfering with those areas which are not as yet occupied. The mechanism responsible for the accumulation of glycogen is, of course, unknown, but it is tempting to speculate that hyperglycemia in diabetic spiny mice leads to a proportional increase of glucose entry into $B$ cells, if we accept LazARow's [24] evidence that the B cell mem- brane is freely permeable to glucose. It would then appear that the amount of glucose which penetrates the cell exceeds the capacity of the cell to oxidize it, and that the excess glucose results in the observed accumulation of glycogen. Normal function would only be totally lost when the cytoplasm has been completely displaced by the accumulation of glycogen.

The vesicular fusion (Fig. 13 and 14) or confluency which we have observed has not, to our knowledge, been previously described in such abundance. It suggests that the membranes surrounding $B$ granules are perhaps more fragile in Acomys than in other species. Contact of one granular vesicle with another, or with any other membrane, would lead to fusion and to destruction of the interposed membrane.

Multinucleated endocrine cells have been occasionally encountered in this material (Fig. 18). These resemble the A-2 cell described by BJörkmanN and collaborators [5]. In the present instance, hovewer, the looseness of the vesicular sacs surrounding the granules $[19,20,27]$, sometimes rectangular-shaped, and the irregular shape and structure of the mitochondria clearly suggest that the cells involved are B cells. While they are more frequently dark, Fig. 18 a contains a cell with a light cytoplasmic area. The "dark" appearance of the cytoplasm in these cells is probably related to an increase in the number of free or membrane-bound ribosomes, as well as to a greater density of the hyaloplasmic matrix, which might be related to diminished cellular hydration. Our observations do not suggest that this is a specific cell type but rather that it represents a functional state of $B$ cells.

The morphologic appearance of the islets of any one animal differs strikingly from islet to islet, and this individuality is also present for the different $B$ cells of the same islet. It would appear that each cell responds individually to the evolution of pathogenetic conditions. Even neighbouring B cells, which might be expected to be in a very similar environment, appear to react individually. Clearly, the state of each cell is the result of the interplay of two systems, one concerning the cellular environment and presumably uniform for all cells, and the other resulting from cellular individuality, which allows for independent reactions to the same alteration of the environment.

Quite generally, the marked pleomorphism observed in the endocrine pancreas of spiny mice suggests not so much an organ as a cellular system, eminently adapted to respond according to environmental changes. Indeed, it would seem to us that the "mixed" or "intermediate" cells, which we have previously described, are part of this more general concept. These intermediate cells have been seen frequently, in several animals and in several islets of the same animal. Together with the other aspects of cellular variability which have just been diseussed, they suggest that, under certain circumstances, the definition of the differentiated cell as a fixed, rigid and immutable unit may be inaccurate. Intermediate cells have been pre- 
viously described by, among others, Lacy [22], HeRMANN and collaborators [17], BJöRKMAN and collaborators [4], Faller [8] and Dieterlen-Lit̀vre [7]. Their observations, as well as ours, strongly suggest to us that adequate stimulation may remove the repression which characterizes the differentiated cell, and thereby restore a part of its embryonic potential, allowing for a new orientation, such as the transformation of exocrine into endocrine function. This view is in keeping with the well-known observations of BRIGGS and KING [6], expanded by FischBerg and collaborators $[9,16]$, demonstrating that the implantation of the nucleus of an already differentiated cell (an intestinal mucosal cell of the tadpole) into the cytoplasm of an egg, may recreate a complete animal. The plasmodial cells, on the other hand, might result from endomitosis and delayed cellular cytodieresis.

Although it is not possible to eliminate totally the possibility of cell fusion, the considerations which we have just detailed lead us to accept the likely pluripotential character of the cell of the endocrine pancreas. Furthermore, our observations in Acomys cahirinus confirm the notion of cellular polymorphism of the islets of Langerhans, a polymorphism which has been described, although to a lesser extent, by other workers reporting on the endocrine pancreas of different species. This has often led to attempts to define many different types of cells. The extreme nature of this phenomenon in the spiny mouse, probably related to hyperplasia and to the occurrence of diabetes, has led to our observing a still larger number of cell types, some of which might well be sequentially related to each other in time. We are therefore led to believe that they do not represent numerous cellular entities with specific and as yet unknown functions, but rather physiologic or metabolic states which are dynamically related and which have been artificially stabilized by fixation. The multiplicity of cell types is greatest in the islets of those animals which clinically showed evidence of early diabetes, thereby suggesting that cellular individuality is best seen in the face of pathologia stimulation, with certain cells retaining the capability for prolonged response to the abnormal requirements, while others may be rapidly eliminated, at least as far as function is concerned.

Finally, these observations in the spiny mouse, when compared with observations in normal rats or mice, suggest that considerable caution should be exercised before the existence of a new and distinat cell type is accepted. The morphological evidence in favour of a new type of cell sould be supported by firm clinical as well as biochemical evidence. The only clearly distinct cell types which we have seen are the A, B and perhaps D cells.

Acknowledgement. The authors aro indebted to Mr. Micher Bernard for his assiduous efforts in the printing of the photographs, and to Mme. JANINE BASST for her tireless devotion to the many difficult technical problems involved in this study.
References

[1] Andre, J.: Contribution à la connaissance du chondriome. J. Ultrastructure Research, Suppl. 3 (1962).

[2] Brunt, C., and K.R. Porter: The fine structure of parenchymal cell of the normal rat liver. General observations. Amer. J. Path. 46, 691-755 (1965).

[3] Caramia, F., B.L. Munger and P.E. Lacy: The ultrastructural basis for the identification of cell types in the pancreatic islets: the guinea pig. Z. Zellforsch. 67, 553-546 (1965).

[4] BJORKMAN, N., and B. HellmaN: Ultrastructure of the istets of Langerhans in the duck. Acta anat. 56, 348-367 (1964)

[5] - C. Hellerströn and B. Hellman: The ultrastucture of the islets of Langerhans in normal and obese hyperglycemic mice. Z. Zellforsch. 58, 803-819 (1963).

[6] BRIGGs, R., and T. KING: Transplantation of living nuclei from blastula cells into enucleated frogs' eggs. Proc. nat. Acad. Sci. \$8, 455-463 (1962).

[7] Dieterlen-Litevre, F.: Etude morphologique et expérimentale de la différenciation du pancréas chez l'embryon de poulet. Bull. Biol. de la France et de la Belgique. Tome XCIX fasc. 1 (1965).

[8] FaLLER, A.: Elekronenmikroskopisehe Untersuchungen über azino-insuläre Übergänge im Pancreas der Ratte. Erg. Heft Anat. Anz. 119 (1966) (in press).

[9] Fiscinberg, M., J.B. Gurdon and T.R. Elsdale: Nuclear transfer in amphibia and the problem of the potentialities of the nuclei of differentiating tissues. Exp. Cell. Res., Suppl. 6, 161-178 (1958).

[10] FuUdkxger, E., and P. Operschade: Die funktionelle Reife der Neurohypophyse bei neonaten Nestflüchtern und Nesthockern. Rev. suisse Zool. 69, 297-301 (1962).

[11] GANsLER, H., and C. Roulliter: Modifications physiologiques et pathologiques du chondriome. Schweiz. Z. Path. 19, 217-243 (1955).

[12] Gomorr, G.: A new stain for elastic tissue. Amer. J. clin. Path. 20, 665 (1950).

[13] GoNet, A.E., J. MougiN, and A. E. Renold: Hyperplasia and hypertrophy of the islets of Langerhans, obesity and diabetes mellitus in the mouse Acomys Dimidiatus. Acta endocr., Suppl. 100, 135 (1965).

[14] - W. Stauffacher, R. Piotet and A.E. Renold: Obesity and diabetes mellitus with striking congenital hyperplasia of the islets of Langerhans in spiny mice (Acomys Cahirinus). Diabetologia 1, 162-171 (1965).

[15] -, and A.E. RENOLD: Homografting of fetal rat pancreas. Diabetologia 1, 91-96 (1965).

[16] GURDON, J.B., and V. UtHLINGER: "Fertile" intestine nuclei. Nature 210, 1240-1241 (1966).

[17] Herman, L., Sato Tamiko and P.J. Fitzgerald: Electron microscopic anatomy. Edit. by S.M. KURTz. Now York: Academic Press 1964.

[18] Karnovsky, M.J.: A simple method for staining with lead at high $\mathrm{pH}$ in electron microscopy. J. biophys. biochem. Cytol. 11, 729-732 (1961).

[19] LACY, P.E.: Electron microscopy of the normal islets of Langerhans. Diabetes 6, 498-507 (1957).

[20] - Electron microscopy identification of different cell types in the islets of Langerhans of the guinea pig, rat, rabbit, and dog. Anat. Rec. 128, 255-268 (1957).

[21] - : Electron microscopy of the islets of Langerhans. Diabetes 11, 509-513 (1962).

[22] - Personnal communication.

[23] Lazarow, A.: Cell types of the islets of Langerhans and the hormones they produce. Diabetes 3, 222-232 (1957). 

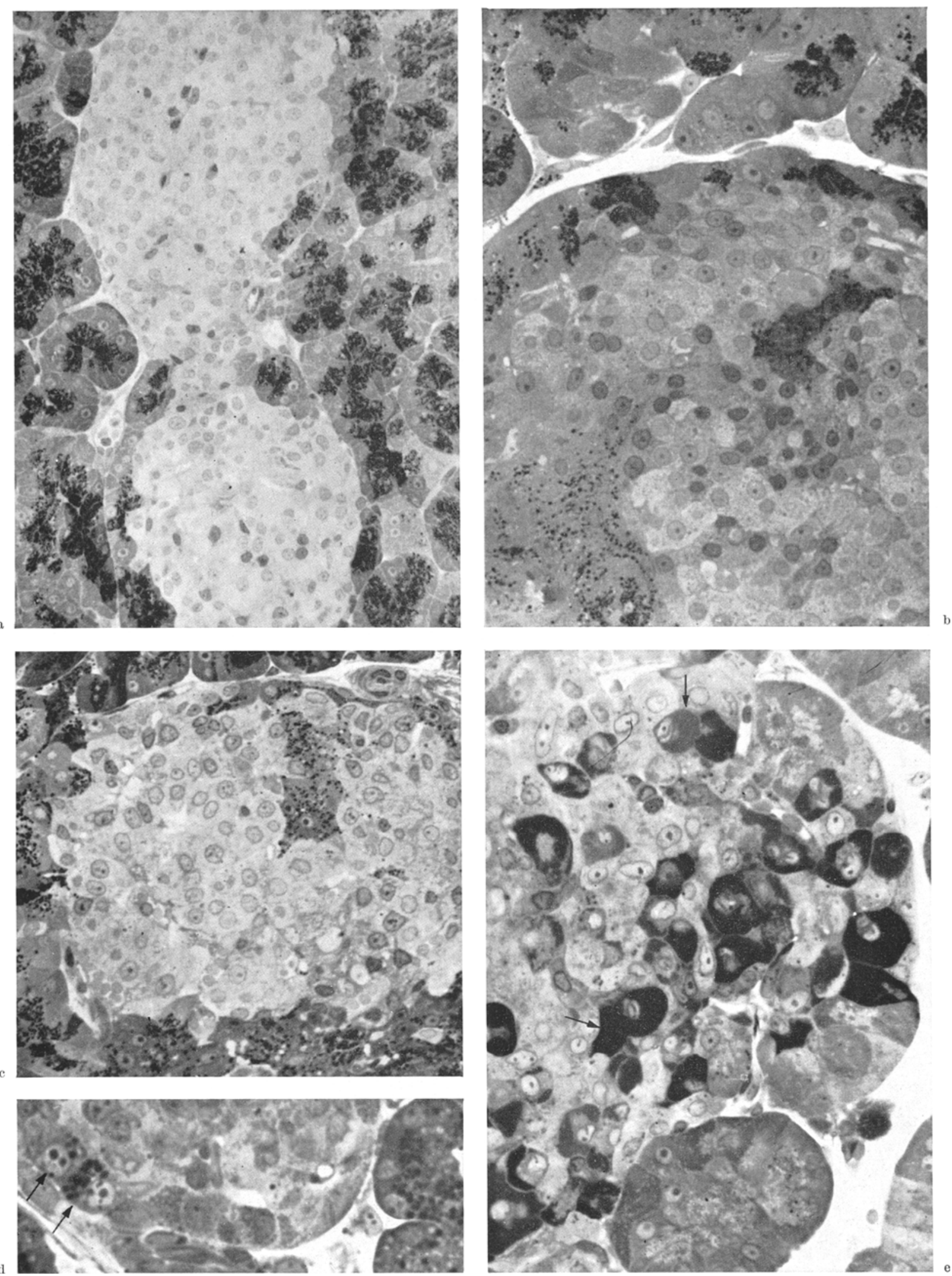

Fig. 3. a) Adult. Junction of two islets. Certain exocrine sells are in close contact with the islets and are not arranged as acini. Semi-thin section,

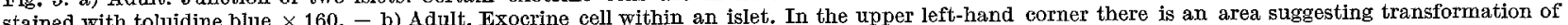
stained with toluidine blue $\times 160$. - b) Adult. Exocrine cell within an islet. In the upper left-hall. Fxocrine cell within an islet. Note some exocrine exocrine into endocrine tissue. Semi-thin section stained with toluidine blue $\times 410 .-c)$ Adult. Exocrine cell within an islet. Note some exocrine (arrow) and A-cells. The $\&$ granules are evident. Semi-thin section, stained with toluidine blue $\times 600$. - e) Adult. Severe diabetes. B celis filled with (arrow) and A-cells. The \& gramules are evident. Sarrow; semi-thin section, stained with toluidine blue $\times 530$ 

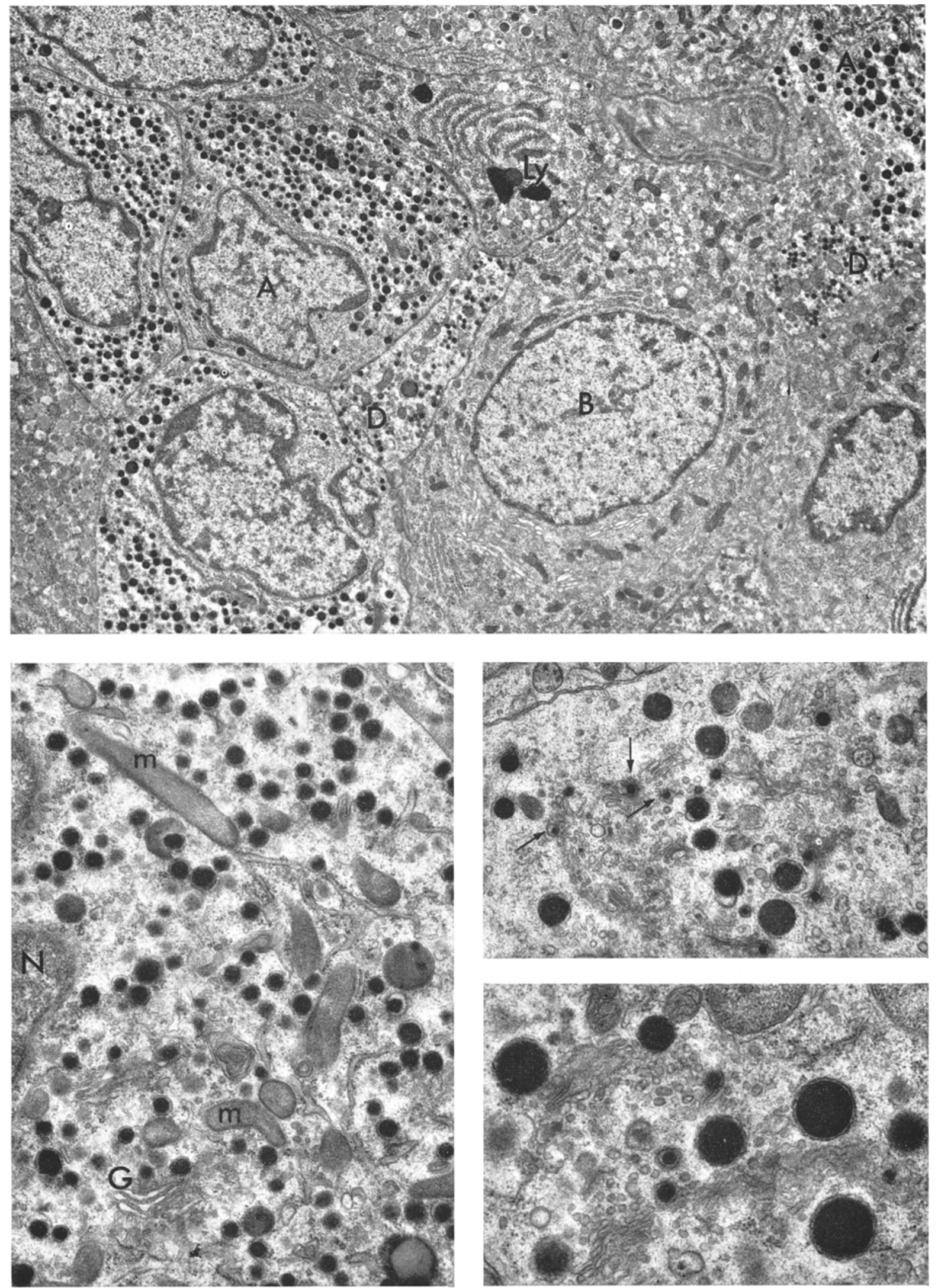

Fig. 4. a) Adult. Intermittent, mild diabetes. A cells (A); perinuclear distribution of the granular endoplasmic reticnlum. The granules are denser than those of B cells (B). Presence of two D cells (D). Lysosomes (Ly). Glutaraldehyde-Osmium $\times 5000 .-$ b) Adult. Severe diabetes. A cell. The granules are in close contact with their vesicles. Note the regular shape of the mitochondria (m). Golgi complex (G). Nucleus (N). Glutaraldehyde-Osmium $\times 24000$. - c) New-born. Golgi complex of A cell. Saccules contain granules being synthetized (arrow). Osmium $\times 17000 .-d$ ) As in $c$ ). Note in addition the great diameter of the granules. Osmium $\times 12000$ 


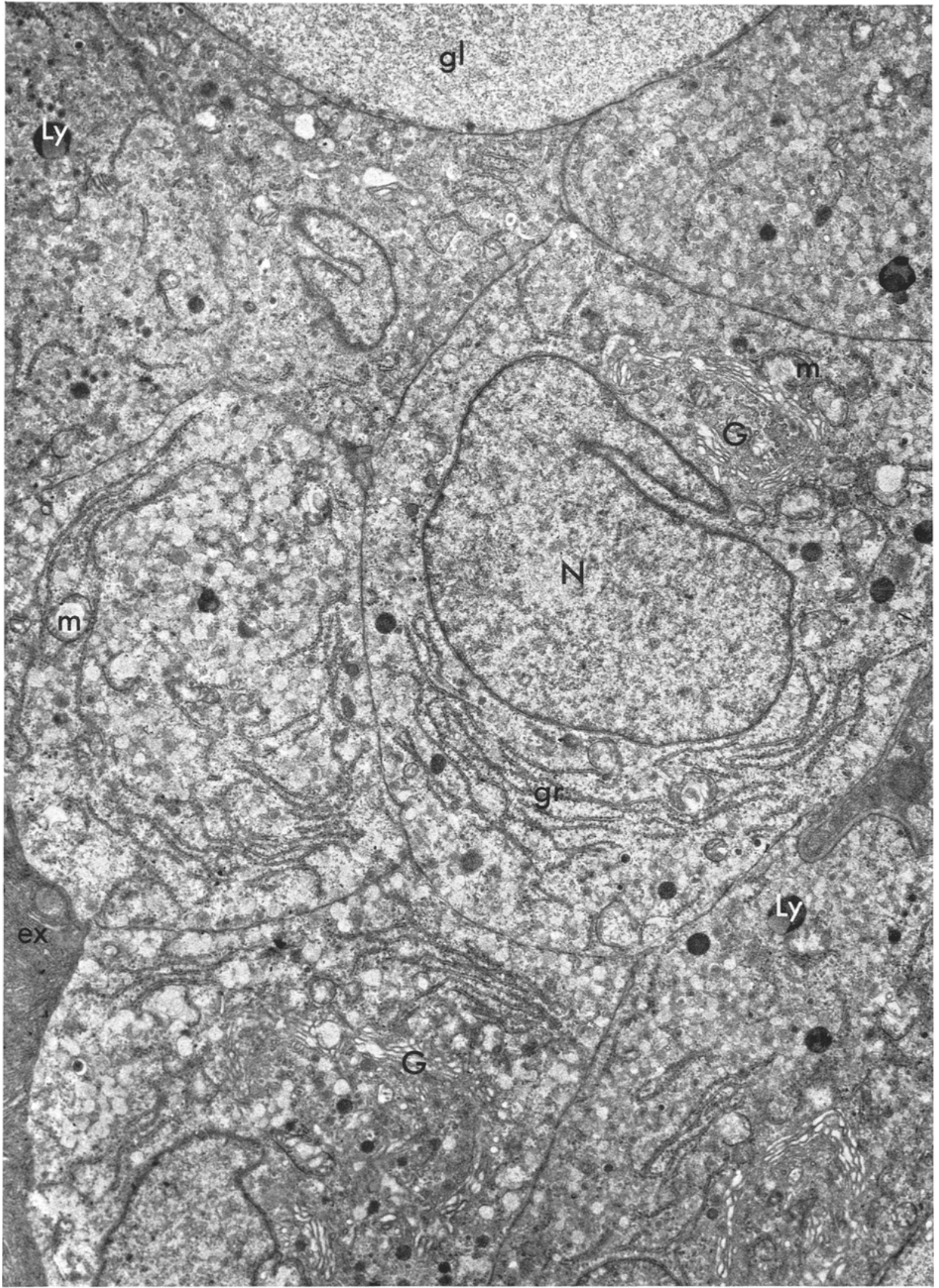

Fig. 5. Adult. Severe diabetes. Grour of B cells. Most of the vesicles are empty or contain a material of low density. The mitochondria are irregularly shaped but not swollen. At top, part of a B cell filled with glycogen. At bottom, left, part of an exocrine cell (ex). Granular reticulum (gr). Golgi complex (G). Mitochondria (m). Lysosomes (Ly). Nucleus (N). Glutaraldehyde-Osmium $\times 7000$ 

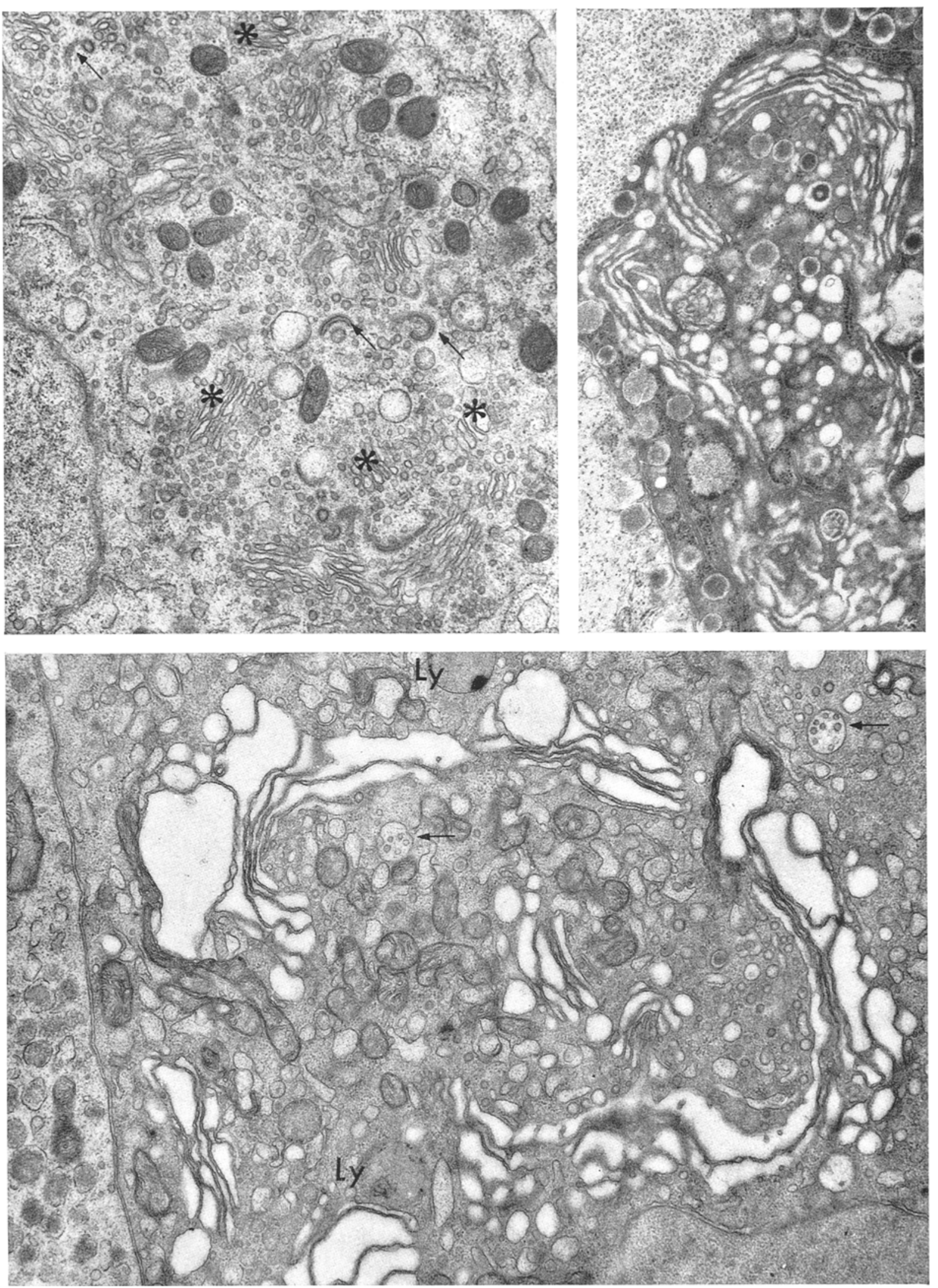

Fig. 6. a) New-born. Golgi complex of a $\mathbf{B}$ cell. At this stage, granules are rare, the Golgi complex is formed by some well individualized dictyosomes*. Note the "coated tubules" (arrow). Osmium $\times 21000$. - b) Adult. Golgi complex of a B cell. It is not possible to establish a relation between the Golgi complex and $\beta$ granules, as was true for A cells. Glutaraldehyde Osmium $\times 21000$. - c) Adult. B cell. Example of hyportrophy of a Golgi complex with dilatation of the external saccules. Presence of lysosomes ( $\mathrm{Ly}$ ) and of multivesicular bodies (arrows). Osmium $\times 19000$ 

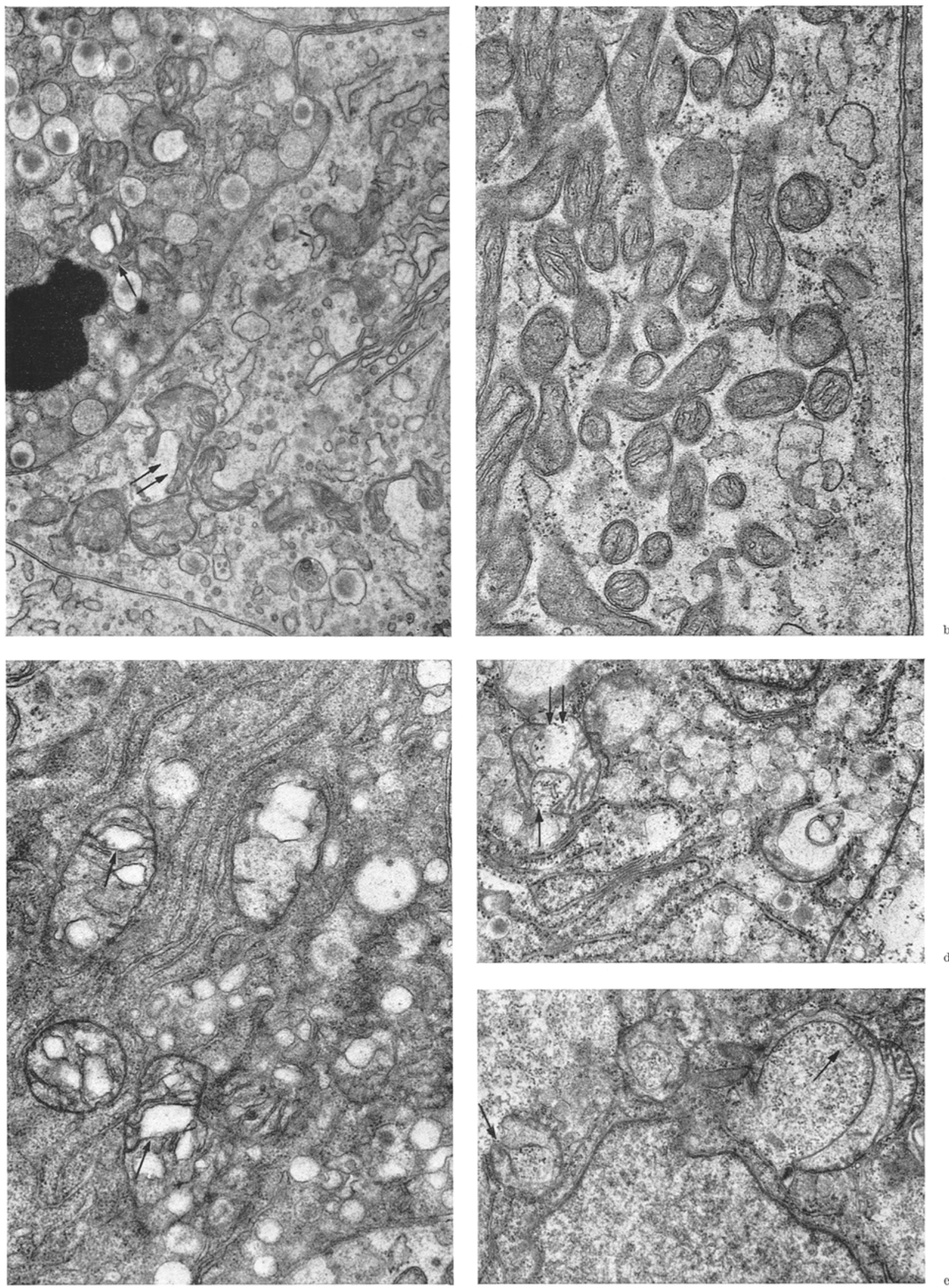

Fig. 7. a) Adult. B cell. Deformation of mitochondria. Note the difference between the deformation as such (arrow) and that secondary to swelling and dilation of cristae. The latter is often followed by runture of the externa mitochondrial membrane (double arrow). Osmium $\times 20000$. - b) Adult. $B$ cell. Area without mitochondrial deformation. The cytoplasm of this type of cell is particularly poor in organelles and ribosomes, and free of granules. Osmium $\times 22000$. - c) Adult. B cell. Dilatation of the mitochondrial cristae (arrows). Osmium $\times 28000$. - d) and e). B cell. Mitochondrial deformation (arrow) and dilatation followed by rupture (double arrow). Glutaraldehyde-Osmium. $\mathrm{d} \times 20000$. e $\times 18000$ 

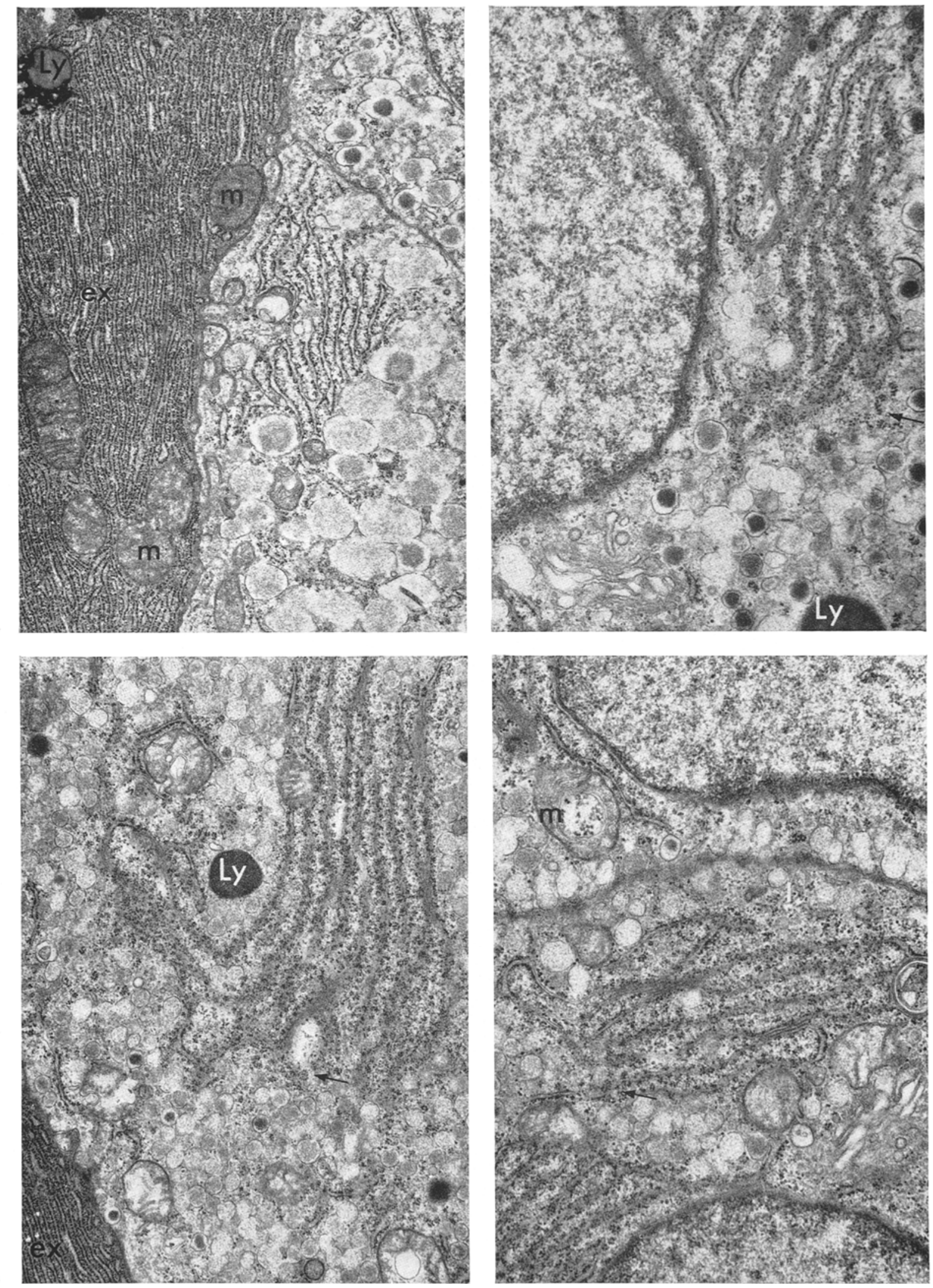


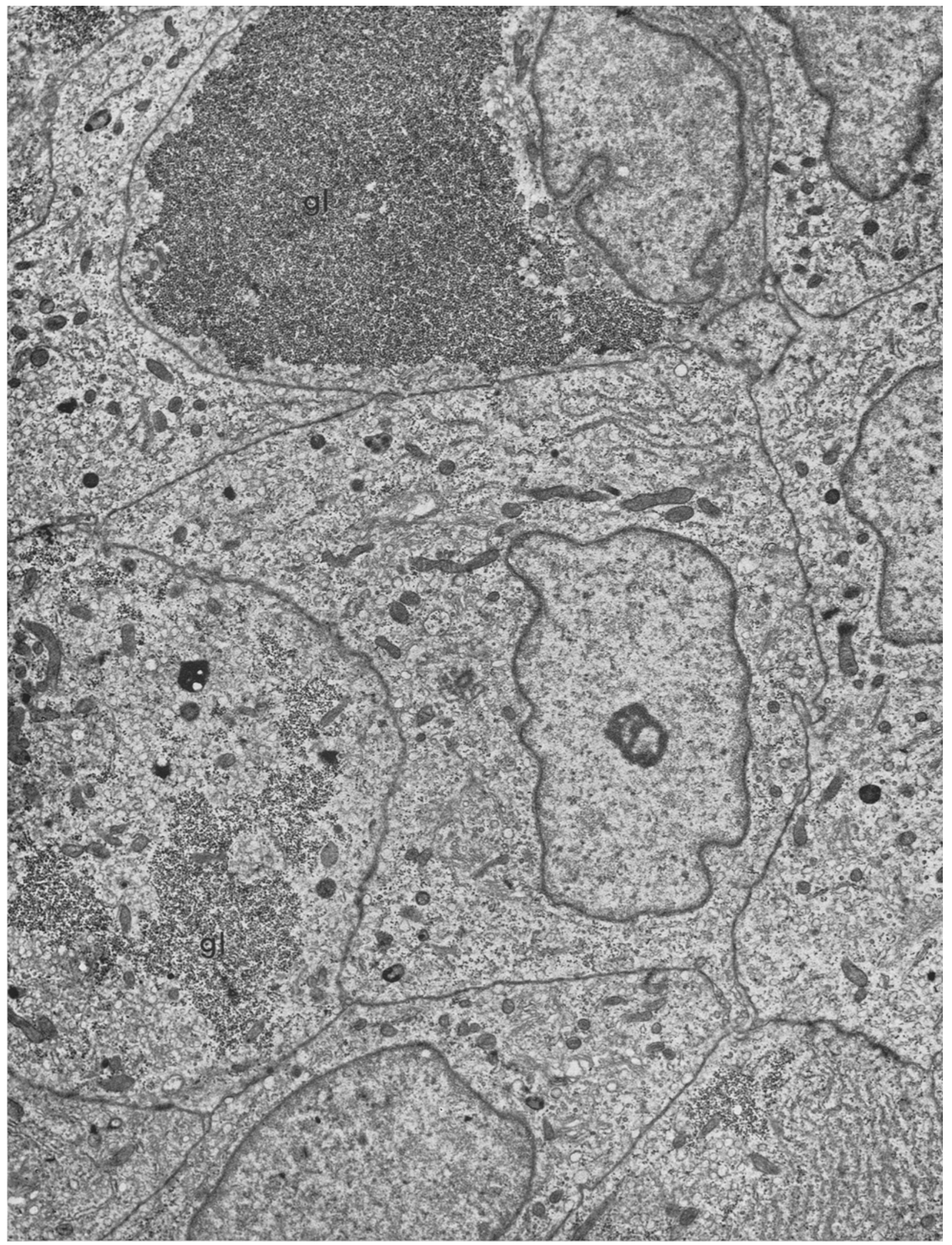

Fig. 9. Adult. Severe diabetes. Group of B cells accumulating glycogen (gl). Note that glycogen may appear most anywhere in the cell in the shape of small granules of high density. Osmium $\times 8500$ 


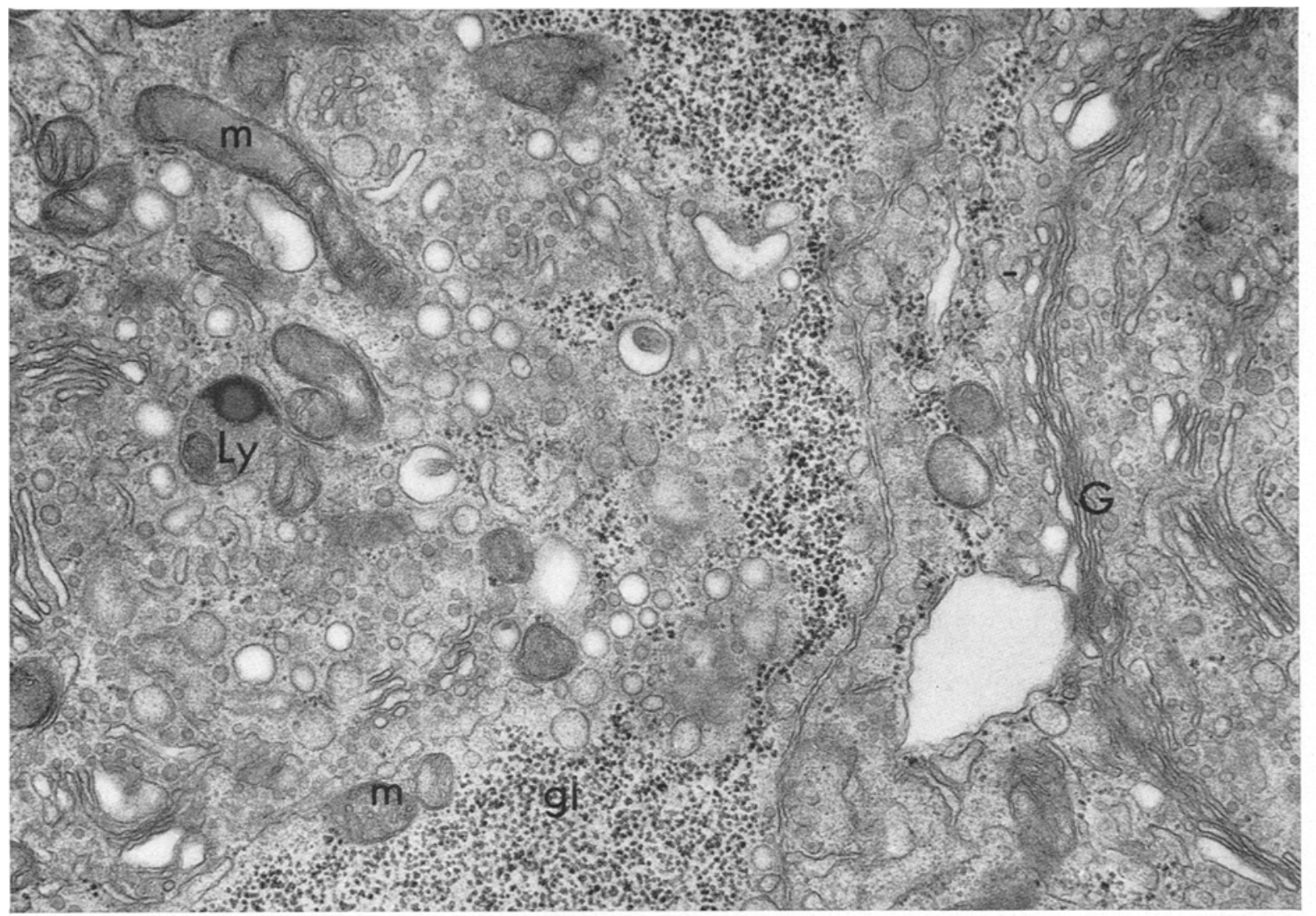

a

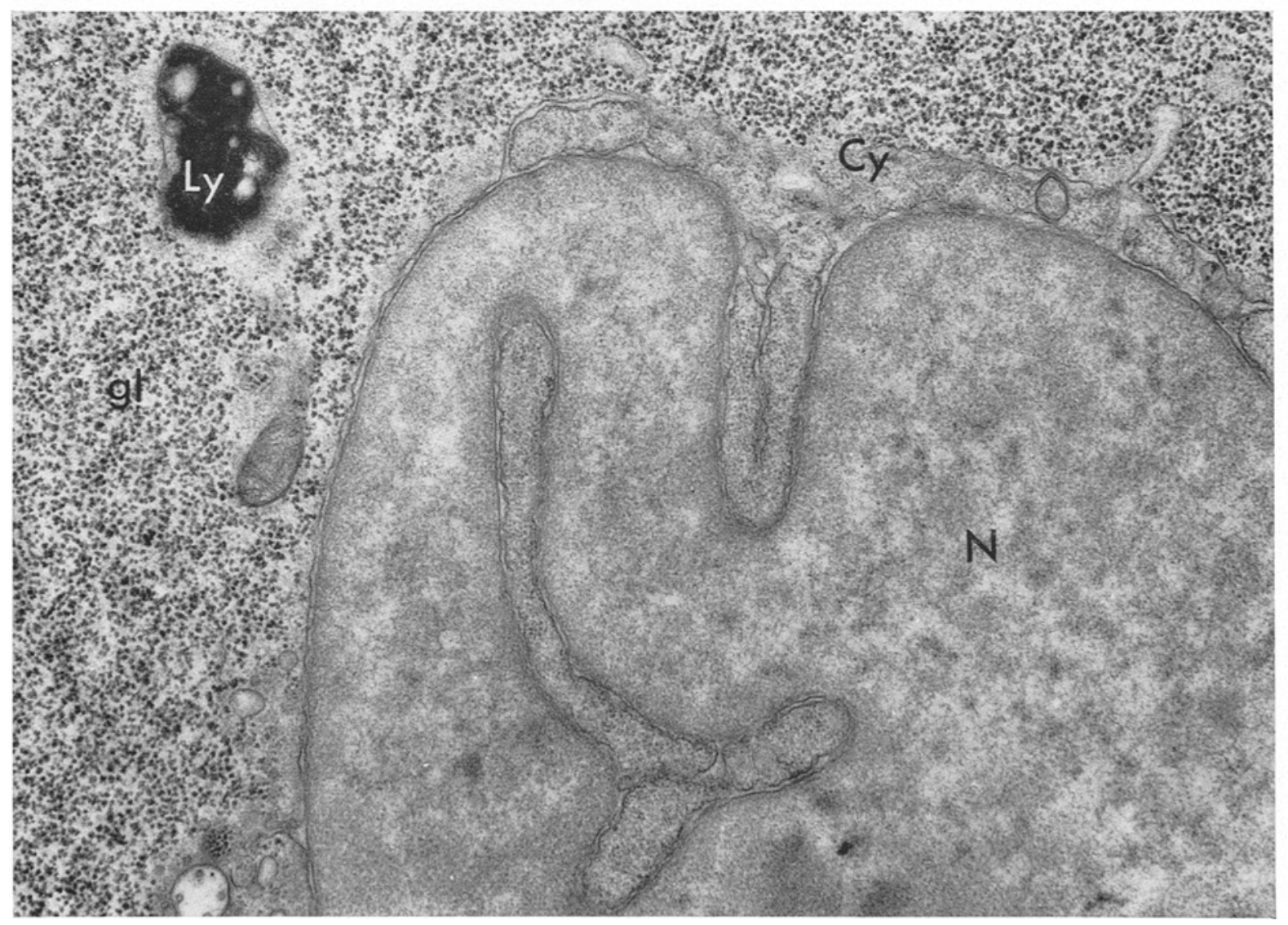

Fig. 10. a) Adult. Severe diabetes. B cells. Glycogen storage (gI) cannot be related to a partieular strueture. Golgi eomplex (G), mitochondria (m), lysosome (Ly). Osmium $\times 22000$. - b) Adult. Severe diabetes. $B$ cell filled with glyeogen (gl). Deformation of a nucleus (N) surrounded by a thin band of eytoplasm (Cy). Lysosome $(\mathrm{Ly})$. Osmium $\times 22000$ 

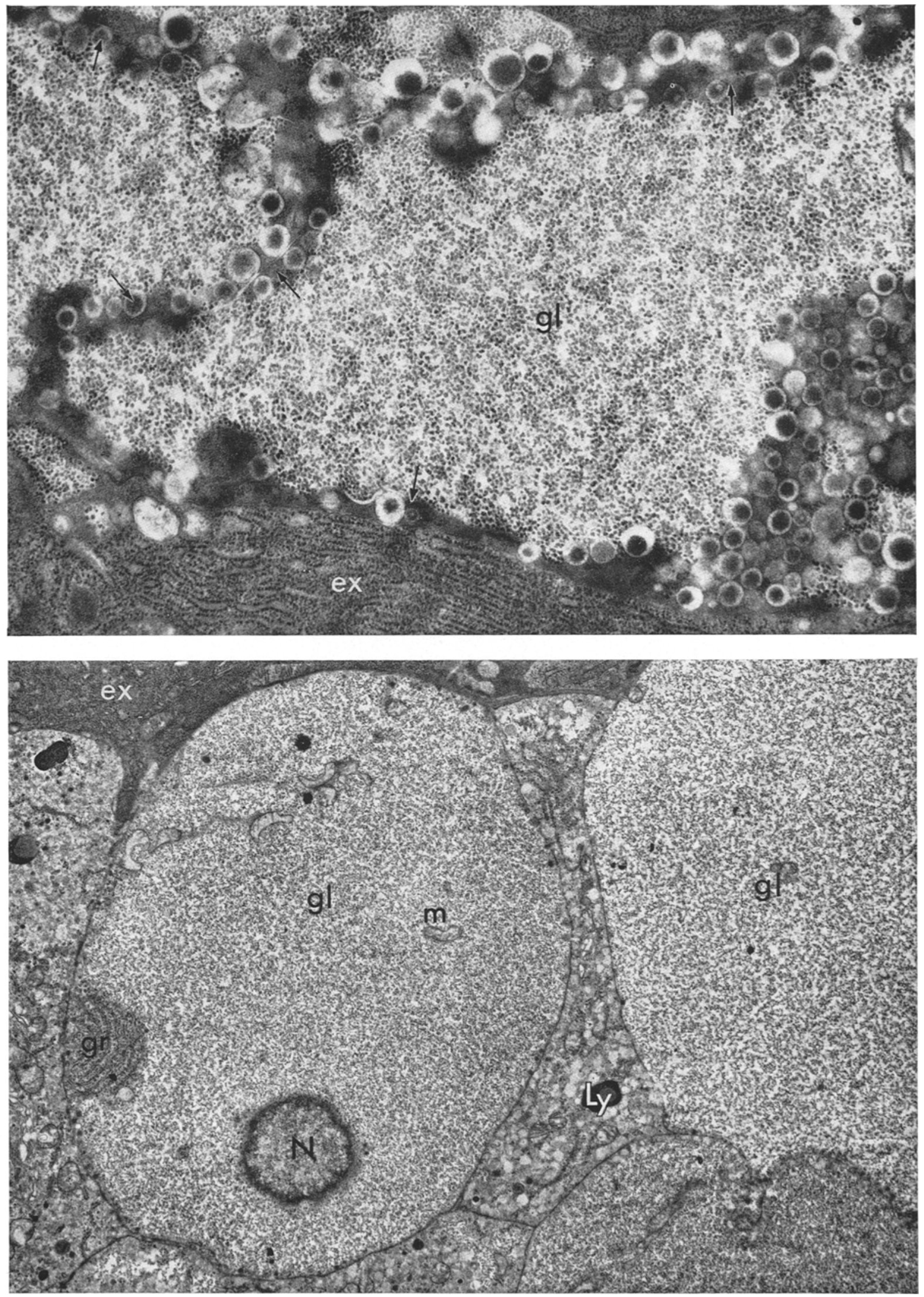

Fig. 11. a) Adult. Severe diabetes. Detail of three B cells showing margination of the cytoplasm and granules (arrows) displaced by glycogen (gl). The large number of cranules demonstrates that Osmium $\times \mathbf{2 4 0 0 0},-$ b) Adult. Severe diabetes. B cells filled with glycogen (gl). Note well-preserved remaining granular endoplasmic reticulum (gr) and mitochondria $(\mathrm{m})$. The nucleus is morphologically normal. Note the differences in the reactions of neighbouring cells. Lysosome (Ly), exocrine pancreas (ex). GlutaraldehydemOsmium $\times 4500$ 


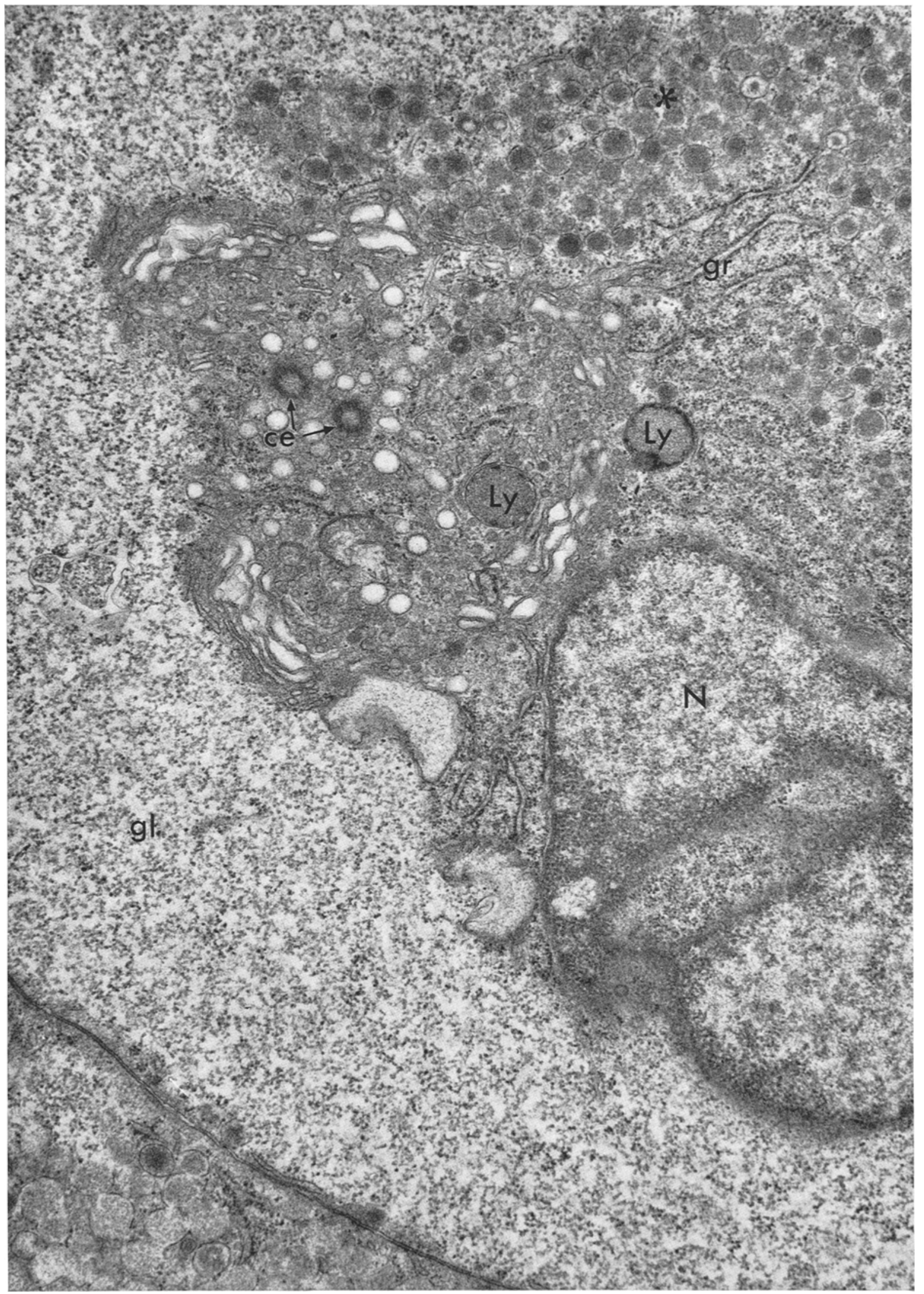

Fig. 12. Adult. Severe diabetes. Detail of a B cell. Note the isolation by glycogen of a cytoplasmic area containing Golgi complex and granular endoplasmic reticulum. This cytoplasm appears functional. Golgi complex (G) with, in its centre, a pair of centrioles (Ce). Lysosomes (Ly), nucleus (N), granular endoplasmic reticnIum (gr), glyeogen (gl). Area of granules (*). Glutaraldehyde 0 smium $\times \mathbf{2 4 0 0 0}$ 


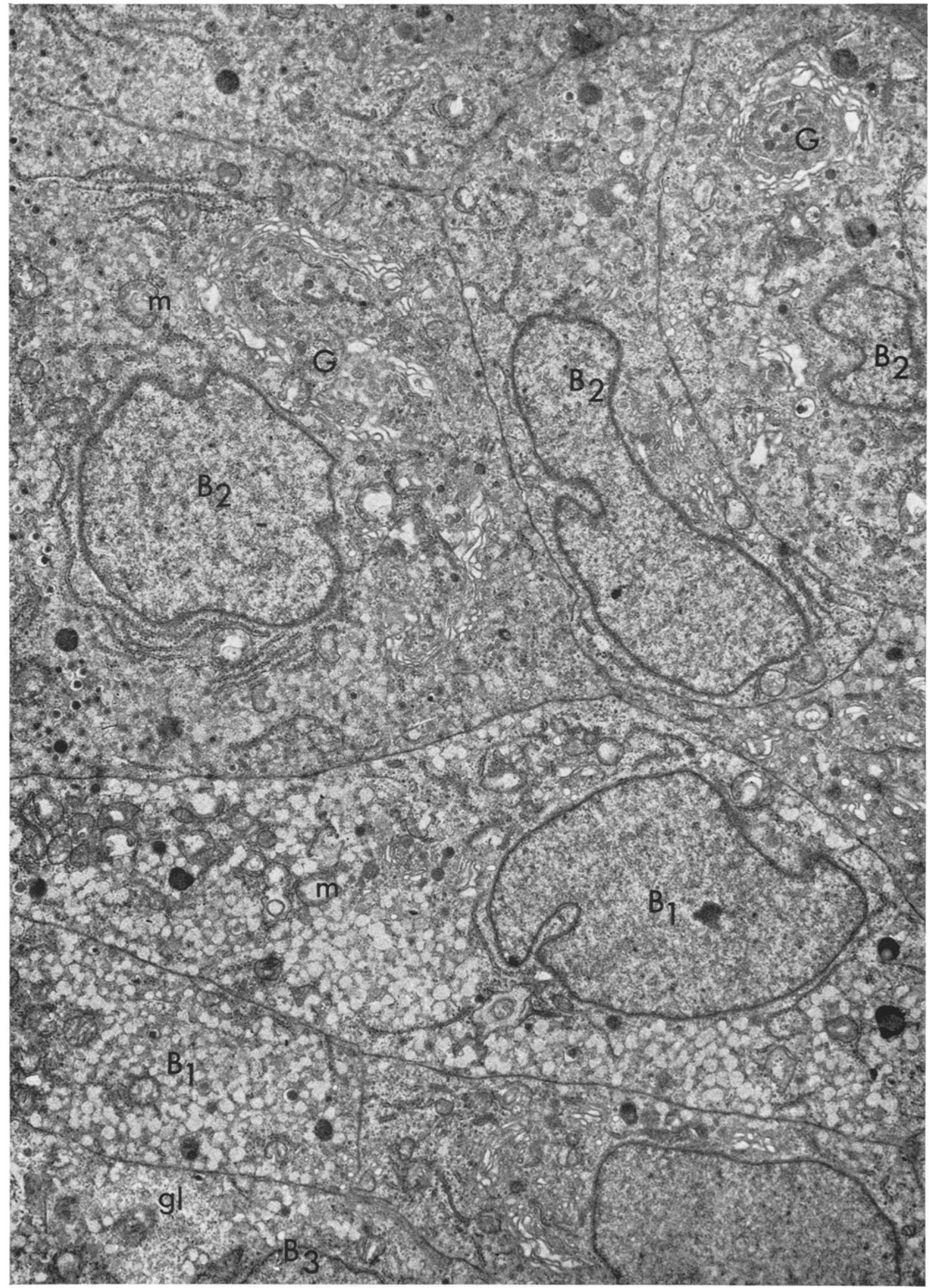

Fig. 13. Adult. Severe diabetes. Group of B cells demonstrating individual variability. Cell with empty vesicles, many confluent (Bl). Ceils with vesicles containing a more or less dense material and some granules (B2). Cell with glycogenic area (gl) (B3). Note the irregularly shaped mitochondria (m) and the prominent Golgi complexes $(G)$. Glutaraldehyde-Osmium $\times 6500$ 

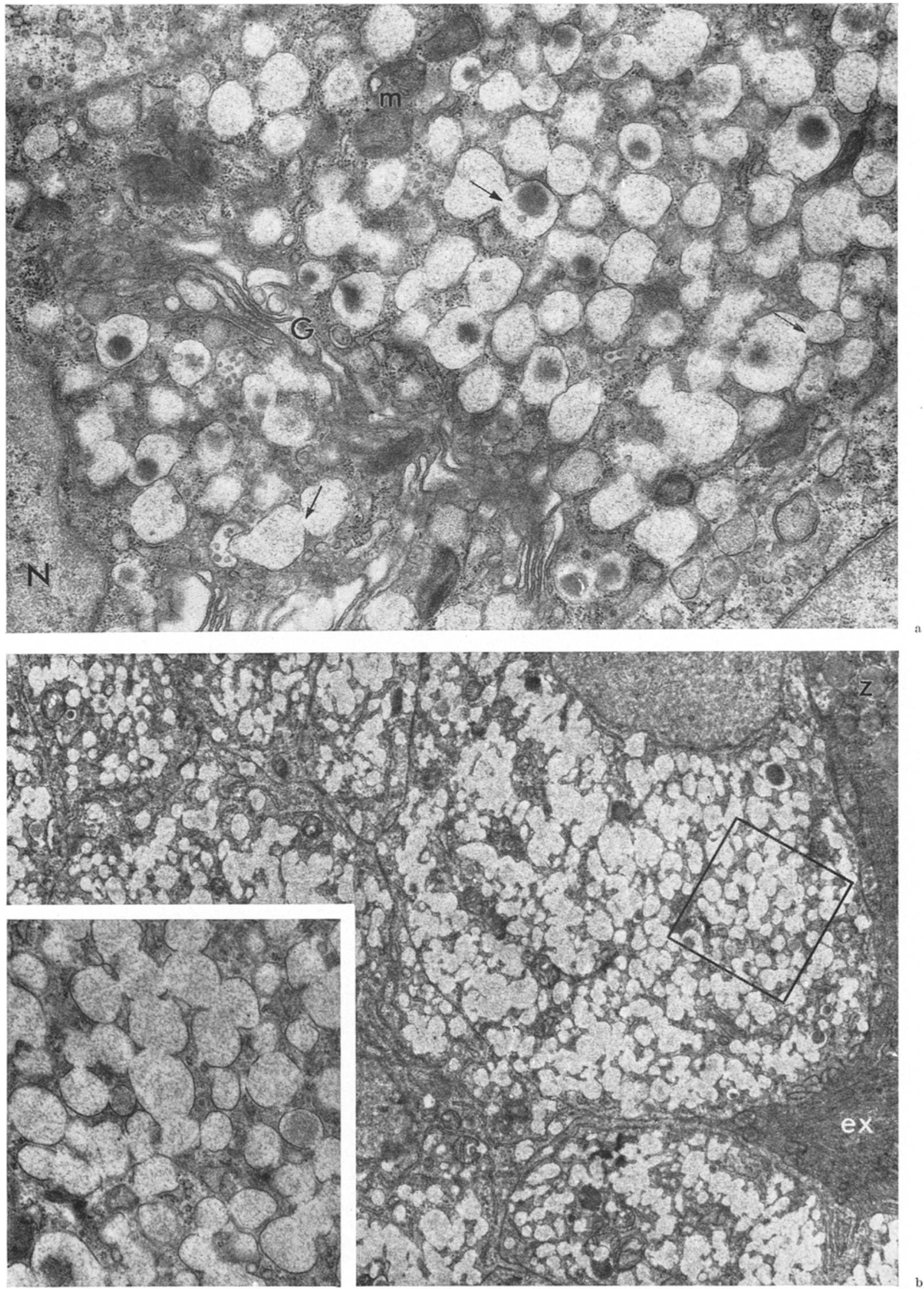

Fig. 14. a) Adult. Intermittent, mild diabetes. B cell. Loss of insulinic granules and beginning fusion of vesicles (arrows). Golgi complex (G), mitochondria $(\mathrm{m})$, nucleus $(\mathrm{N})$. Osmium $\times 17000$. $-\mathrm{b}$ ) Adult. Intermittent, mild diabetes. B cells at an advanced stage of vesicular fusion. Almost completely degranulated. On the right, exocrine cell (ex) with zymogen granules (z). Glutaraldehyde-Osmium $\times 6000$. - c) Detail of b). Rosette- 

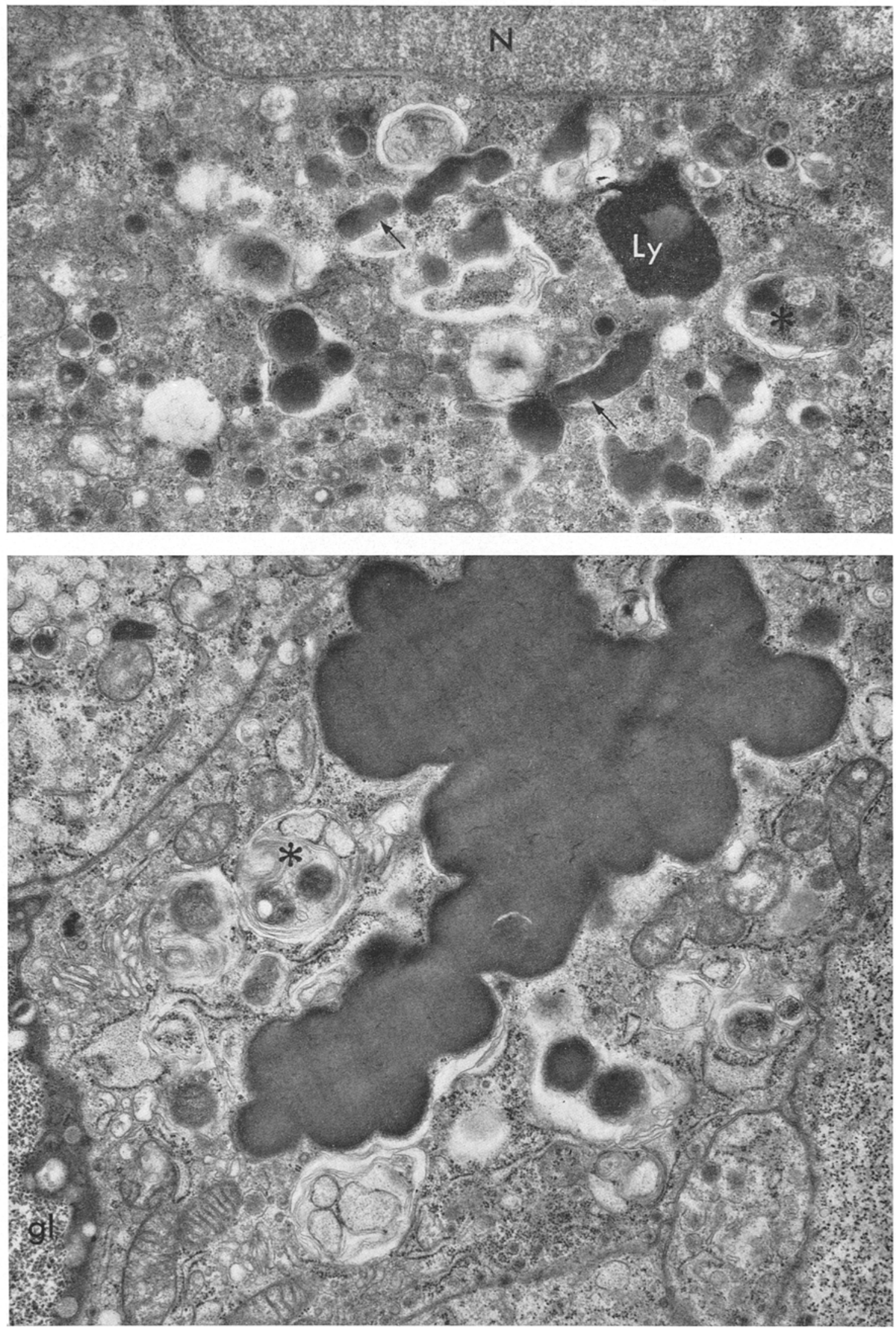

Fig. 15. a) Adult. Moderate diabetes. B cellular degeneration. Fusion of insulinic granules (arrows). Presence of phagosomes which might participate in the formation of the lacquered areas. Iysosome (Ly), nucleus. (N). Glutaraldehyde-Osmium $\times 17000$. - b) Adult. Severe diabetes. More advanced degeneration. At bottom, left, margination of granules in a B cell filled with glycogen (gl). Phagosomes (*). Glutaraldehyde-Osmium $\times 17000$ 

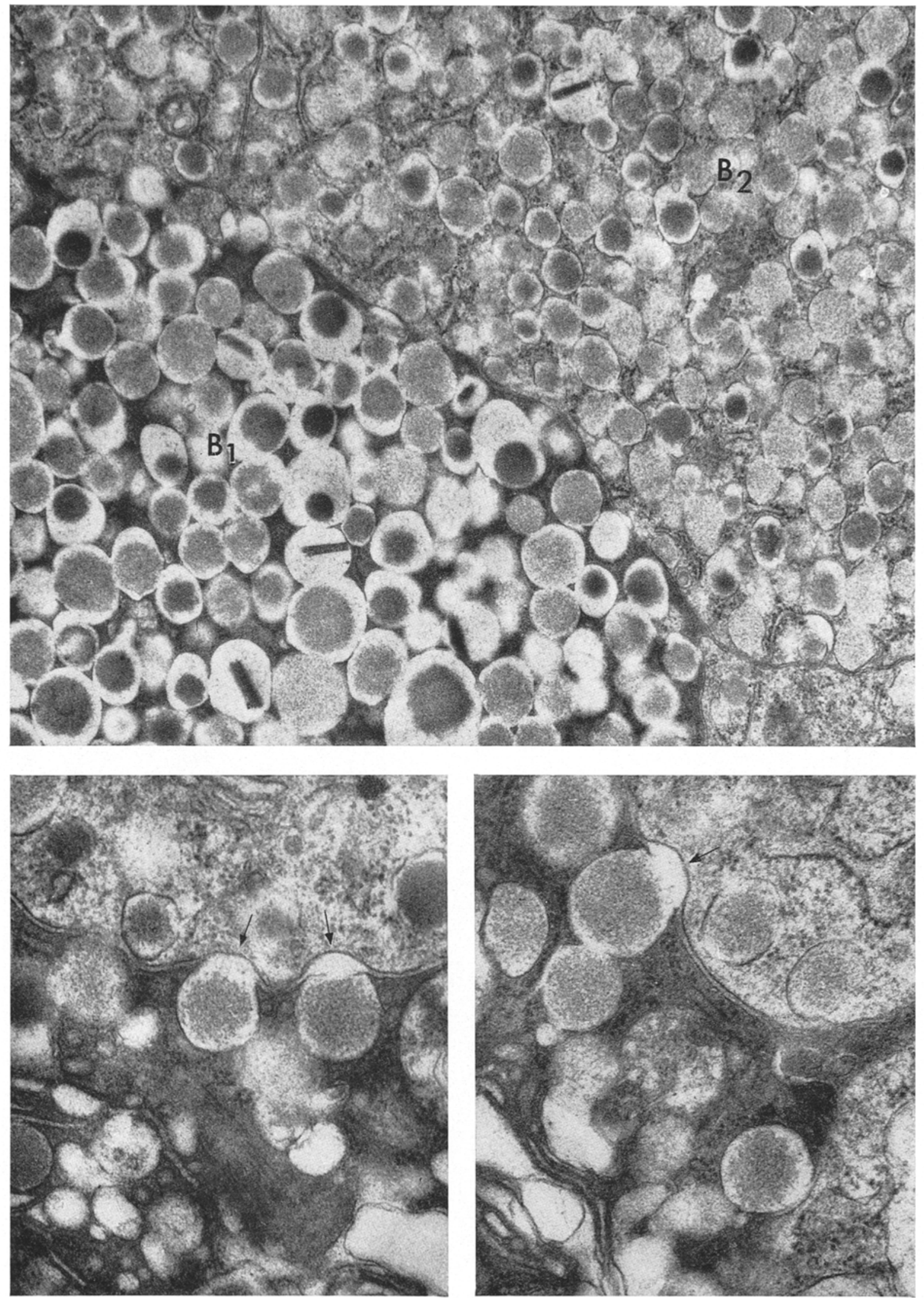

Fig. 16. a, b, c. Adult. Intermittent glycosuria. Two hyper-granulated B cells, dark (BI) and light (B 2). The large number of granules is not necessarily related to the density of the hyaloplasm, thereby eliminating the possibility that the large quantity of granules results from dehydration and contraction of the cell. Note the rectangular-shaped crystalloid structure of the content of some vesicles and the variable thensity of the material in others. Note also the large size of some vesicles in the dark cells. Arrows indicate emeiocy tosis. Glutaraldehyde-Osmium $(\mathrm{a} \times 29000, \mathrm{~b}, \mathrm{c} \times 42000)$ 


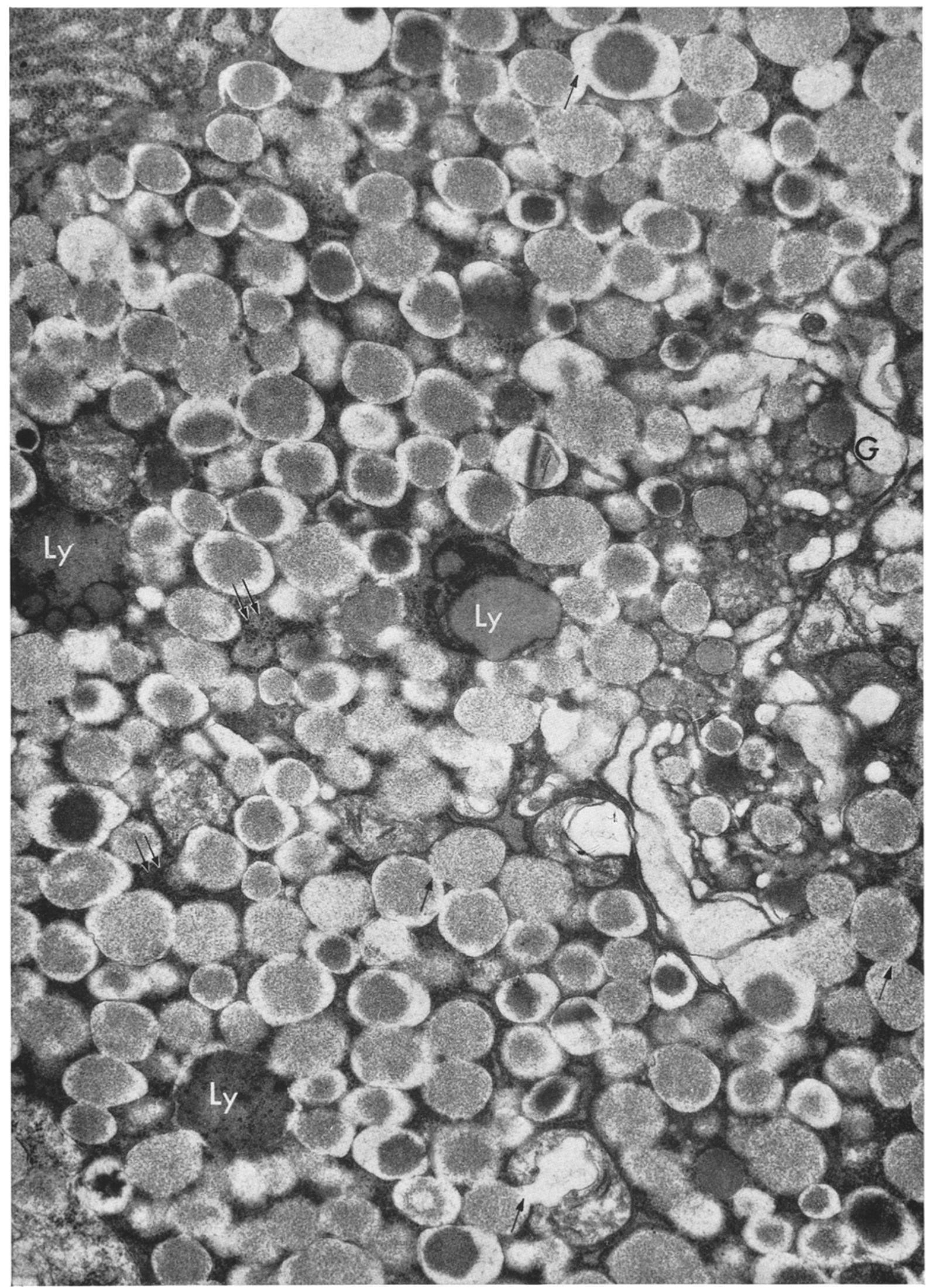

Fig. 17. Adult. Intermittent glycosuria. Part of a hypergranulated cell. Note the variable appearance of intravesicular material and the fusion of some vesicles with other vesicles or membranes (arrows). Golgi complex (G). Lysosomes (Ly). Note also the many ribosomes between the vesicles (double arrows). Glutaraldehyde-0smium $\times 23000$ 

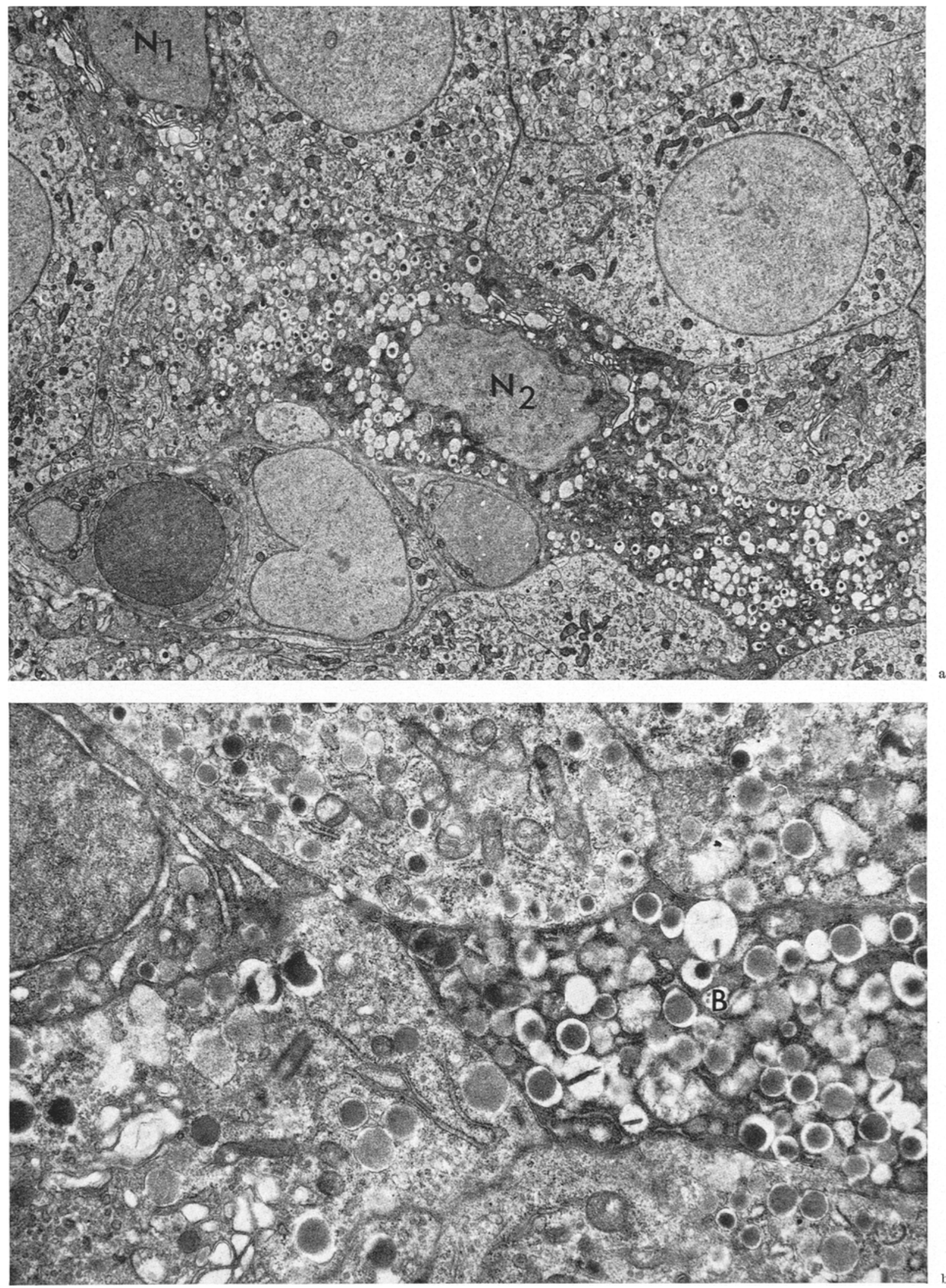

Fig. 18. a) Adult. Intermittent glycosuria. Plasmodial cell. Two nuclei can be seen (N1 and N2). The B character of this cell is suggested by the variable density of its cytoplasm and the small granules in relation to the vesicles. Osmium $\times 4000$. - b) Adult. Non-diabetic. A cluster of B cells, one of which (B) is densely granulated and appears to be transitional between the type of cell described in a) and the hypergranulated cells of Fig. 15 and 16 . Glutaraldehyde-Osmium $\times 18000$ 

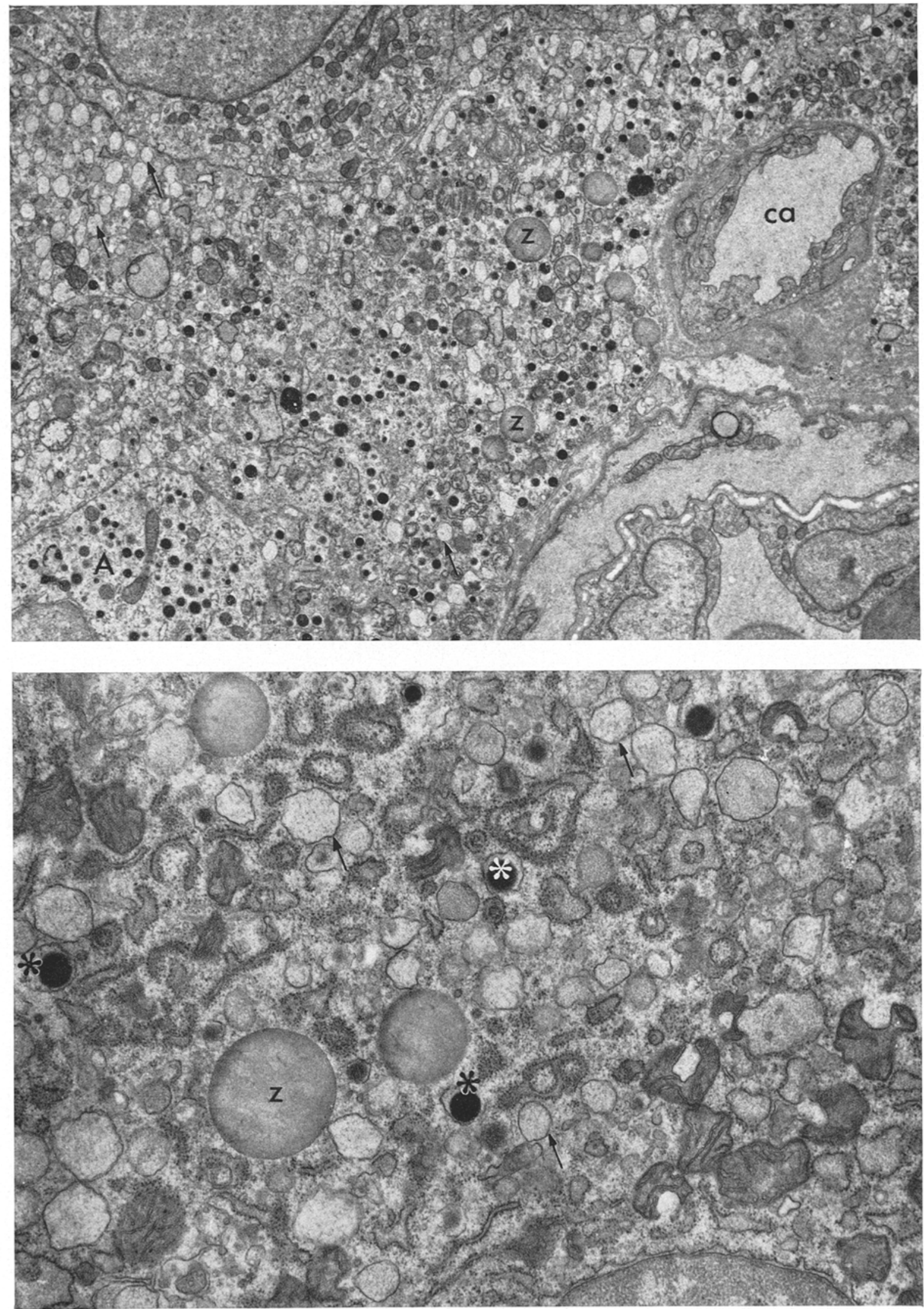

Fig. 19. a) Adult. Obese but non-diabetic. Mixed cell with three eharacters. A granules can be recognized by their variable diameter for a constant density; B vesicles appear empty after osmium fixation (arrows), and zymogen granules ( $\mathrm{z}$ ) are recognized by their size and appearance. A cell (A), capillary (ca). At bottom, right, an arteriole. Osmium $\times 6000 .-$ b) Aduit. Obese but non-diabetic. Detail of mixed cell with three characters. Note the absence of limiting membrane between the different structures. $\alpha$ vesicles and granules $(*), \beta$ vesicles (arrows), zymogen granules (z). 
[24] -- P.K. Dixit, A. Lindati, J. Moran, K. HostertLER and S.J. COOPERSTEIN : Enzyme specialization of islet tissue. In: Symposium on the structure and metabolism of the pancreatic islet, eds. S. E. BroLIN, B. Heulman and H. Knutson, p. 249-268. Oxford: Pergamon Press 1964.

[25] LehNinger, A.L.: The Mitochondrion. New York: W.A. Benjalita, Inc. 1964.

[26] LENTz, T.: Intramitochondrial glycogen granules in digestive cells of hydra. J. cell. Biol. 29, 162-167 (1966).

[27] Like, A. A., J. Steinke, E. E. Jones and G. F. CAHILL Jr.: Pancreatic studies in mice with spontaneous diabetes mellitus. Amer. J. Path. 46, 621-644 (1965).

[28] LUFT, J.H.: Improvements in Epoxy resin embedding methods. J. biophys. biochem. Cytol. 9, $409-414$ (1961).

[29] MrLIs, M., and L. Orcr: La microscopia a contrasto di fase su ultrasezioni di tessuti e le sue applicazioni in biologia. La Ricerca scientifica 34, Rendiconti B 4, 365-410 (1964).

[30] - Electron microscopic observations on mice lzidney in osmotic nephrosis with glucose. Unpublished data.

[31] Merdini, D., and F.G. Caramia: Electron microscopic study of the cells of the human pancreatic islets. Rev. int. Hepat. 16, 687-693 (1965).

[32] Munger, B.L., F. Caramia and P.E. Lacy: The ultrastructural basis for the identification of cell types in the pancreatic islets. II. Rabbit, dog and opossum. Z. Zellforsch. 67, 776-798 (1965).

[33] Pictet, R., and A.E. Gonet: Cellules mixtes (exocrines et endocrines) dans le pancréas de la souris à piquants, Acomys Cahirinus. C.R Acad. Sci. Paris 262, 1123-1125 (1966).

[34] -, and L. ORCI: Electron microscopic observations on brown adipose tissue of the fetal rat. Unpublished data.

[35] Renold, A.E., A.E. Gonet, W. Stauffadher and B. JEANRENAUD : Laboratory animals with spontaneous diabetes and/or obesity: suggested suitability for the study of spontaneous atherosclerosis. International Symposium on Recent Advances in Atherosclerosis, Athens, "in press".

[36] SEL.JELID, R., and I.I.E. ERTCSSON: An electron microscopic study of mitochondria in renal clear cell carcinoma. J. Mieroscopy 4, 759-770 (1965).

[37] SмIтH, U., and D.S. SMITH: Observations on the secretory processes in the corpus cardiacum of the stick insect, Carausius morosus. J. cell. Sci. 1, 59-66 (1966).

[38] VoLK, B.V., and S.S. Lazarus: Ultramicroscopic evolution of B-cell ballooning degeneration in diabetic dogs. Lab. Invest. 127, 697-711 (1963).

[39] - - and K.F. W ELLMANN: $\beta$-cell structure in latent and chronic diabetes of the rabbit. Diabetes 14, 792-804 (1965).

[40] WeIss, M.: The release of pituitary secretion in the platyfish, Xiphophorus maculatus (Guenther). Z. Zellforsch. 68, 783-799 (1965).

Docteur Raymond Pictet Dept. of Histology and Embryology and Dept. of Clinical Biochemistry Sentier de la Roseraie CH-1211 Genève 4, Switzerland 